\title{
Role of Financial Services in Economic Growth: Policy Implications for Pakistan
}

\author{
Jamshed Y. Uppal* and Inayat U. Mangla**
}

\begin{abstract}
In the last two decades, the financial services sector in Pakistan has seen remarkable growth and structural development. However, it is debatable whether the financial markets and institutions have contributed meaningfully towards promoting growth in the real economy. This paper provides a brief background of the theoretical and empirical literature on the linkage between the financial services sector and economic growth. It evaluates the development of Pakistan's financial markets and institutions in comparison to a cohort of developing countries. The country's governance and regulatory environment in light of these theories and the empirical evidence is compared with other countries. The weaknesses in the linkages between finance and economic growth are identified within the framework of the theoretical models and relevant empirical evidence. The final section discusses the challenges Pakistan faces in making its financial services sector become an effective driver of economic growth.
\end{abstract}

Keywords: Financial services, economic growth, Pakistan.

JEL classification: $\mathrm{O} 16$.

\section{Background}

Notwithstanding the earlier dismissal by neo-classical economists of the role of finance in economic development (Lucas, 1988; Robinson, 1952), the nexus between the development of financial sectors and economic growth is now so widely accepted that "[the idea] that financial markets contribute to economic growth is a proposition too obvious for serious discussion" (Miller, 1998). Pioneering studies by Gurley and Shaw (1955) and McKinnon (1973) firmly established the finance-growth link, which is well-stated in the following: "The preponderance of theoretical reasoning and empirical evidence suggests a positive, first-order

\footnotetext{
* Associate Professor of Finance, Catholic University of America, Washington DC. Email: uppal@cua.edu

** Professor Emeritus, Western Michigan University, Michigan. Professor of Finance, Lahore School of Economics. E-mail: inayat.mangla@wmich.edu
} 
relationship between financial development and economic growth" (Levine, 1997, p. x).

The theoretical underpinning and the empirical evidence are summarized in review studies such as those by Thiel (2001) and Levine (2005). The economic theory and extant empirical evidence also suggest plausible rationales for why well-functioning financial systems matter for growth: by reducing information costs and allocating capital; monitoring firm behavior and exerting corporate governance; facilitating the hedging, trading, and pooling of risk; mobilizing savings for investment; and reducing the transactions costs of economic exchange and activity.

The key message for economic policy-makers which emerges from the understanding of the finance-growth nexus is that financial development should be a crucial piece in any country's strategy for economic growth. In particular, developing countries need to strengthen institutional infrastructure by building effective legal and regulatory frameworks, and adopting best accounting and auditing standards and practices. The Global Financial Crisis (2008-09) has underscored the havoc that financial instability can wreak on the real economy and the critical importance of financial stability for growth. A resilient financial sector bolstered by prudential regulation will better equip developing countries to deal with the speed and scope of financial innovation, and new financial products, services and technologies in a globalized world.

In the last couple of decades, the financial services sector in Pakistan has seen remarkable growth and structural development. However, it is debatable if its financial markets and institutions have contributed meaningfully towards promoting growth in the real economy. This paper provides a brief background of the theoretical and empirical literature on the linkage between the financial services sector and economic growth. Next, it evaluates the development of Pakistan's financial markets and institutions in comparison to a cohort of developing countries. The country's governance and regulatory environment in light of these theories and the empirical evidence is compared with other countries. The weaknesses in the linkages between finance, economic growth and governance are identified within the framework of the theoretical models and the relevant empirical evidence. The final section discusses the challenges Pakistan faces in its financial services sector becoming an effective driver of economic growth and proposes policy recommendations. 


\section{Finance and Growth}

Among development economists, a consensus has emerged that a well-functioning financial sector is a precondition for the efficient allocation of resources and for achieving an economy's full potential for growth. Levine $(2005,2004)$ has presented a comprehensive review of the theory and evidence on the connections between the operation of the financial system and economic growth. The study concluded that "the preponderance of evidence suggests that both financial intermediaries and markets matter for growth and that reverse causality alone is not driving this relationship." This implies that "better developed financial systems ease external financing constraints facing firms, which illuminates one mechanism through which financial development influences economic growth." Thiel (2001) showed that "financial development is related to economic growth even in industrial countries."

Among the more recent studies, Durusu-Ciftci, Ispir and Yetkiner (2017) have shown that debt from credit markets and equity from stock markets are two long-run determinants of GDP per capita. Their empirical study of 40 countries over the period 1989-2011 revealed that "both channels have positive long-run effects on steady-state level of GDP per capita, and the contribution of the credit markets is substantially greater." With reference to the developing and Asian countries, Estrada, Park and Ramayandi (2010) argued that sound and efficient financial systems are especially important for sustaining growth "because efficiency of investment will overshadow quantity of investment as the driver of growth in the region." Their panel data study of 125 countries has confirmed that financial development has a significant positive effect on growth, especially in developing countries, supporting the notion that further development of the financial sector matters for sustaining growth. Zhang, Wang and Wang (2012) used data from 286 Chinese cities over the period 2001-06 to investigate the relationship between financial development and economic growth. Their results suggest that most traditional indicators of financial development are positively associated with economic growth and that finance-growth linkages are present even in countries where the banking sector is state-ruled (e.g., China). Masoud and Hardaker (2012) presented an empirical analysis of the relationship between financial development and economic growth for 42 emerging markets. Their results indicated that "stock market development has a significant effect on economic growth, and this effect remains strong even after the influence of banking sector and other control variables." Their findings suggest that the stock market and the banking sector play a complementary role in the economy. 
In the wake of the 2008 Global Financial Crisis (GFC), serious concerns have been raised about the disruptive potential of finance for economic growth. Such issues have been detailed in a number of studies. For example, Yongseok (2013) has argued that developed financial markets are still an essential ingredient of long-run economic growth. Cournède and Denk (2015) have shown that while finance has been a key ingredient of longterm economic growth in the Organisation for Economic Co-operation and Development (OECD) and G20 countries over the past half-century, there can be too much finance, that is, at some levels of household and business credit, "further expansion slows rather than boosts growth." Cecchetti and Kharroubi (2015) have explored the possible crowding out of real economic growth by the financial sector, suggesting that the growth of a country's financial system can be a drag on productivity growth, since "financial booms are not, in general, growth-enhancing, likely because the financial sector competes with the rest of the economy for resources." Further, they have concluded that credit booms harm what we normally think of as the engines for growth - those that are more R\&D intensive. The contagion effects of the GFC were amplified by the globalized nature of the financial industry and led to economic disruptions and crisis across the globe. According to a report by the Group of Thirty (2013), "Globally, cross-border capital flows increased from US\$4.9 trillion in 2000 to US\$11.7 trillion in 2007. Nearly 60 percent of this growth was driven by cross-border lending, but most of this was short-term in nature." The implications are that developing countries need to prioritize enabling more stable flows of long-term capital.

The recent experience during the GFC suggests that the relationship of finance and real economic growth needs to be reexamined to identify both the growth-enhancing and the growth-retarding roles of finance. Economic growth strategies attach considerable weight to the development of efficiently functioning and complete financial markets. By fostering the development of the financial services sector, a country's economic growth would be accelerated. Emphasis is placed on policy measures that lead to the deepening of financial markets that include, in particular, institutional and legal measures to strengthen creditor rights, investor rights and contract enforcement.

However, there is still a wide divergence of opinions as to how and to what extent finance affects economic growth. Outstanding questions are pertinent for implementing strategies for the development of the financial sector as an engine for economic growth. Three questions require particular attention: (1) How does financial sector development lead to economic growth?; (2) what features of the financial sector structure provide 
maximum support to economic growth?; and (3) how do financial structures lead to structural changes in the economy and technological progress?

Though it is now empirically well-established that financial development leads to economic growth, empirical analysis at the aggregate level does not capture the complexities of the financial structures and the multiple channels through which finance and the growth processes are linked. For such reasons, it is more instructive to study these issues at the country level. This paper reviews the underlying conduits between financial developments and economic growth, and seeks to apply the principles identified in the academic literature to the three questions with reference to the role of Pakistan's financial sector. We seek to identify weaknesses in the transmission channels and suggest remedial measures such that the financial services sector may play a robust role in economic growth.

\section{How Does Finance Affect Economic Growth?}

Economic growth depends upon the accumulation of production input factors and technical progress. Traditionally, finance has been linked primarily with the accumulation of capital leading to economic growth. Furthermore, finance makes it possible to realize technical progress as technical advances are embedded in the capital stock. In growth theory under the assumption of perfect markets, the interest rate brings into equilibrium the economy's savings and investment. Therefore, in the presence of perfect markets, the financial sector is "nothing but a veil on the true determinants of economic developments," and financing decisions become irrelevant. Over time there has been recognition of the problems arising out of asymmetric information and how it affects financial contracting between borrowers and lenders.

In dealing with the problems associated with asymmetric information, adverse selection and agency costs, the financial system assumes a more prominent role in facilitating an efficient allocation of capital. Financial institutions specialize in evaluating and monitoring investment opportunities, and thus obtain a comparative advantage in evaluating risks and designing financial contracts. In particular, banks build up information advantages from lasting relations with borrowers from accumulated experience. They also enjoy economies of scale from offering transaction services. Therefore, an increase in the efficiency of the financial system would lead to higher rates of economic growth.

The finance-growth nexus, in theory, may run through various transmission channels. Thiel (2001) has put these into three main 
categories, stating that financial development: (1) reduces the transaction costs required to allocate capital; (2) increases the savings ratio; and (3) raises capital productivity. Lower transaction costs mean more efficient transformation of savings into investment, and that more net savings can be used for productive investments. A more efficient financial system improves the return-risk combinations for savers. It is uncertain, however, whether it can induce an increase of the saving ratio and thus stimulate higher economic growth. Financial development raises the productivity of capital through: (1) more efficient allocation of capital over investment projects; (2) the provision of liquidity; and (3) the allocation of risks. The development of the financial sector has an ongoing effect as it leads to a durable positive feedback effect between finance and growth.

The financial system contributes to economic development by reducing costs associated with acquiring information, enforcing contracts and conducting transactions. Financial systems also mitigate problems of moral hazard and adverse selection by producing information on investment returns, facilitating a more efficient allocation of resources. By providing diversification and risk-sharing opportunities, the financial systems also help mobilize saving and efficient intermediation of financial resources.

\section{Governance, Financial Development and Growth}

The main role of financial development is tackling the imperfections in the capital markets, and a growing body of research points to a strong link between corporate governance measures and financial development. Financial markets' depth and breadth is associated with higher quality institutions in general, including better property rights and rule of law (North, 1981; La Porta, Lopez-de-Silanes, Shleifer, \& Vishny, 1999). La Porta, Lopez-de-Silanes, Shleifer, and Vishny $(1997,1998)$ have provided empirical evidence that measures of investor protection derived from corporate law are associated with stock market development. La Porta, Lopez-de-Silanes and Shleifer (2006) have examined the effect of securities laws on stock market development and have found strong evidence that laws mandating disclosure and facilitating private enforcement through liability rules benefit stock markets. Similarly, Burger and Warnock (2006) have concluded that policies and laws matter in the development of the local currency bond market. Their analysis indicated that both creditor-friendly policies and creditor-friendly laws can play an effective role in bond market development. They have shown that "strong rule of law is associated with deeper local bond markets, whereas countries with better creditor rights are able to issue a higher share of bonds in their 
local currency." In the context of Pakistan, Uppal $(2007,2011)$ has provided evidence that the securities laws play an important role in the development of bond markets, because they facilitate private contracting rather than public enforcement.

Acknowledging the nexus between development and governance, World Bank's World Development Report for 2017 is subtitled "Governance and the Law". Governance is defined as "the process through which state and non-state actors interact to design and implement policies within a given set of formal and informal rules that shape and are shaped by power." The report addresses three core development outcomes: security, growth, and equity. It advocates that "commitment, coordination, and cooperation fundamentally underlie the effectiveness of policies to promote these outcomes, but the unequal distribution of power can constrain policy effectiveness."

Figure 1 presents a conceptual mapping of the linkages running from the governance and regulatory environment to lessening of the market imperfection and to a more effective role of the financial sector in economic growth.

Figure 1: Governance, Market Imperfections and Financial Sector's Role

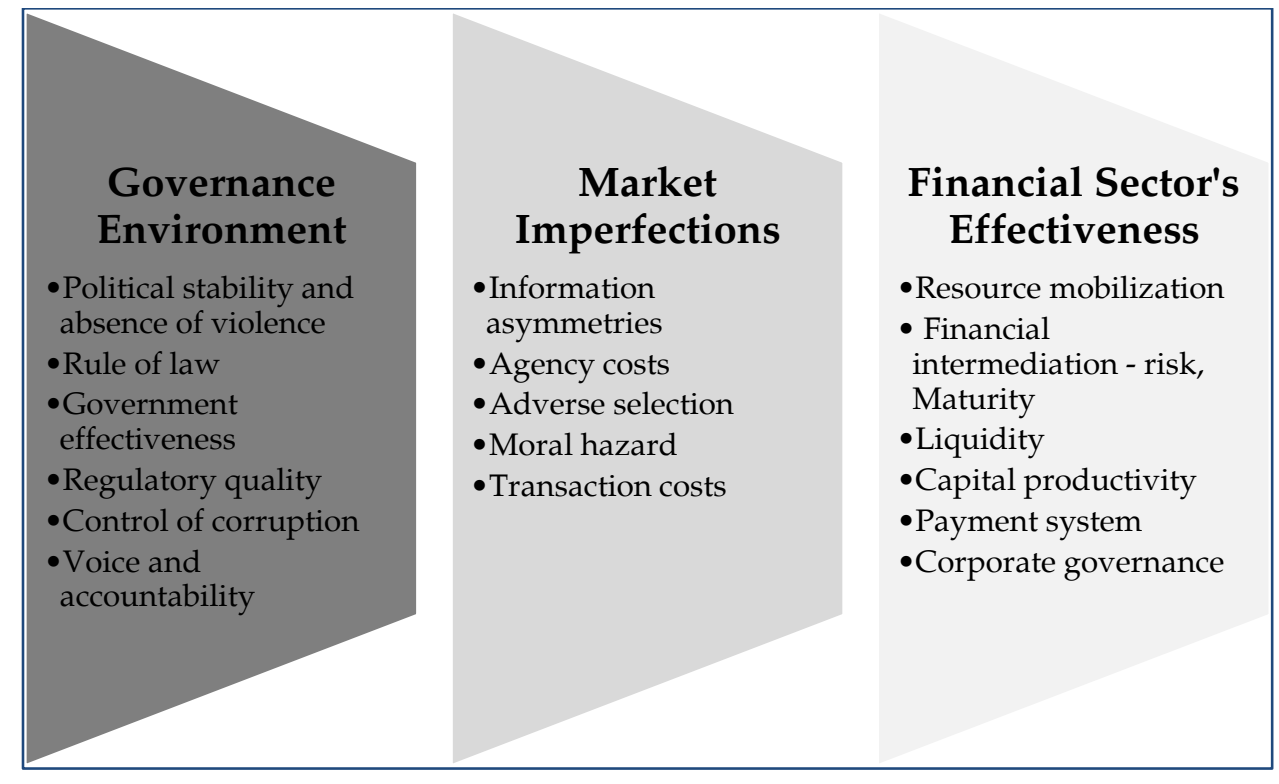

Source: World Bank, 2006. 


\section{Patterns of Corporate Financing in Pakistan}

The fundamental role of finance is to channel savings to investment. Therefore, it is instructive to examine how corporations in Pakistan have sourced funds to finance their operating assets up to now. Table 1 summarizes the liabilities and equity structure of the private corporations listed on the Karachi Stock Exchange (KSE) for the years 2011-2016. The data show that the shareholders' equity dominates the sources of funding at 44.2 percent in 2016. While it is consistent with the pecking order hypothesis whereby corporations' first choice is to use internally generated funds for investments, the steady trend of increasing use of equity over the six year period is notable; equity ratio increased from 35.9 percent in 2011 to 44.2 percent in 2016. While the overall equity ratio increased, the paid-up-capital decreased, from 14.0 percent to 12.2 percent, but equity reserves increased from 21.9 percent to 32.0 percent over the same period. 


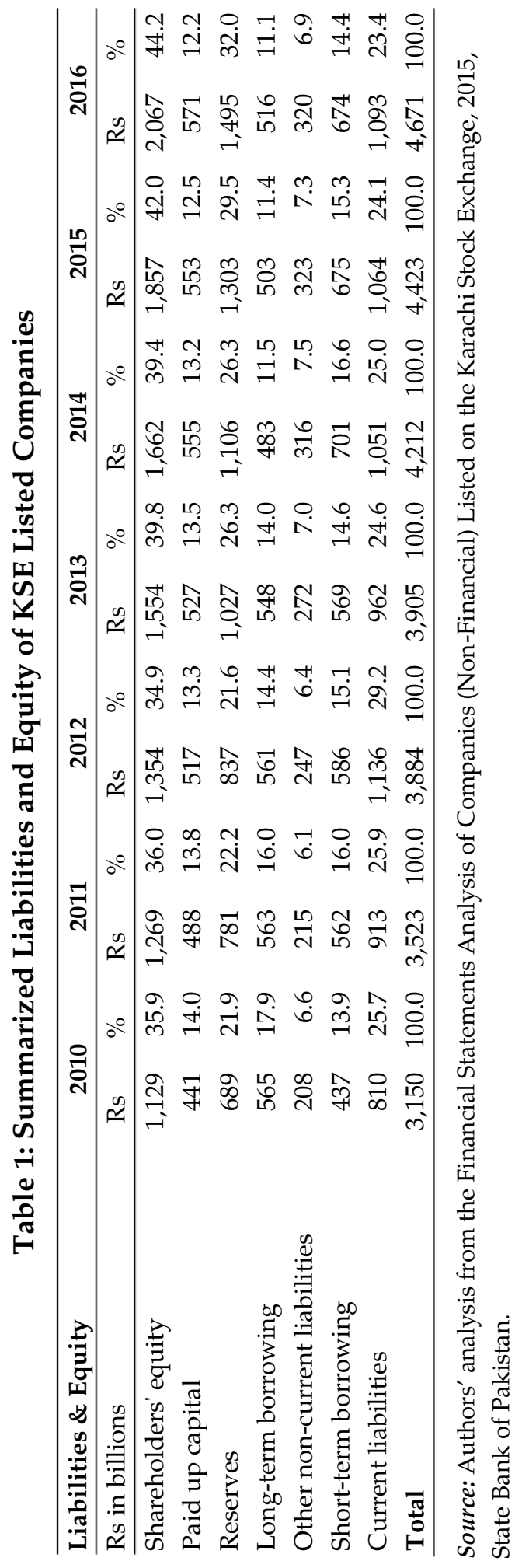


At the same time, we observed a lowering of the long-term debt ratios; long-term borrowing decreased as a percentage from 17.9 percent to 11.1 percent over the five year period. There was also an increase in the use of short-term borrowing; from 13.9 percent to 14.4 percent and a greater reliance on other non-current liabilities (e.g., employees benefit obligations) and current liabilities (e.g., trade credit).

The increasing use of internally generated funds indicates a trend of moving away from engagement with the financial sector, either with the banking sector for long-term loans or the financial markets for debt or equity issues. It implies that the pecking order considerations are increasingly dominating corporations' funding decisions. It points to an aggravation of the problems originating in informational asymmetry and agency cost on which the pecking order hypothesis is based.

Further insights are obtained by examining the corporate sectors' uses and sources of funds. This is presented in Table 2 in a format which shows the amounts and the percent of the funds raised (or remitted) in relation to the corporations' total investments. 


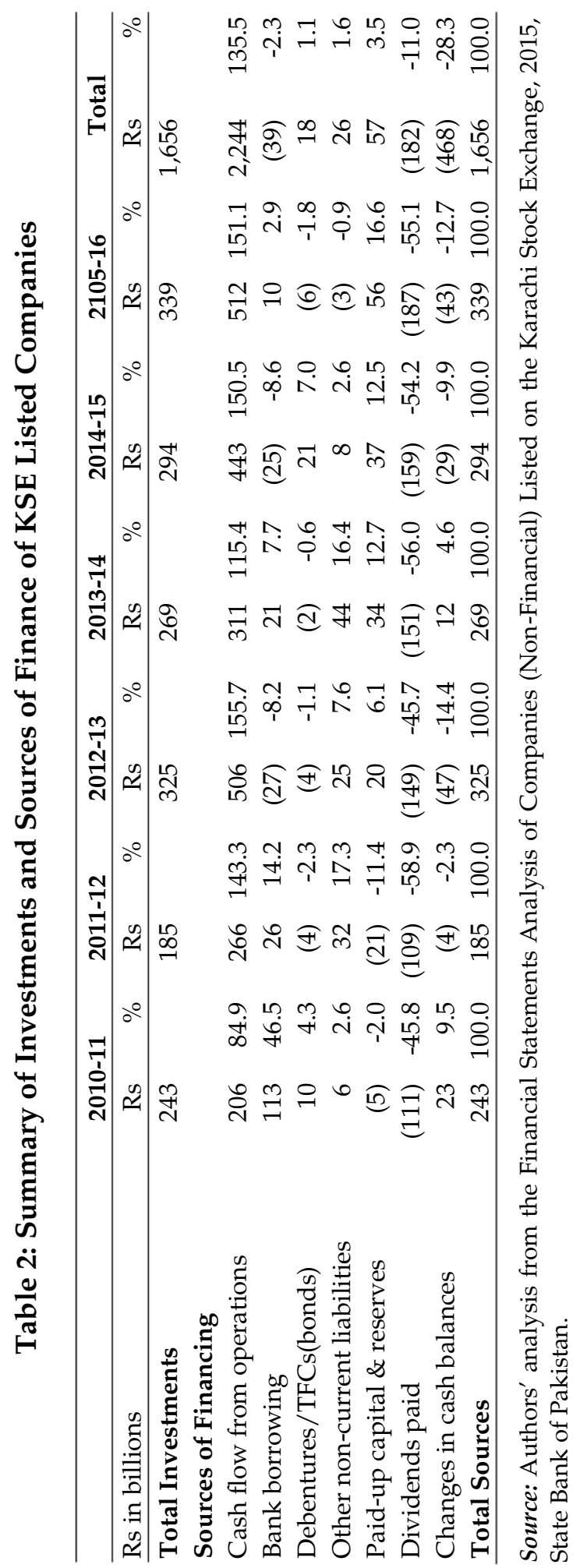


Table 2 shows that for the six-year period, the cash flow from operations-generated funds was overall in excess (135 percent) of the investment need of the sector. Though the contribution of the operating cash flows to the investment requirements of the firms varies (min 85 percent, max 151 percent) from year to year, it is the dominant source. Bank borrowing or additional paid-up capital is not a major source, and the least important source is the financial securities, debentures and TFCs (bonds). The operating cash flows typically provide a surplus which is used to pay back loans and distribute substantial dividends. The dividends are so far in excess of the additional equity capital (from new equity issues/reserves) that there seems to be a drawdown of the capital by the shareholders, rather than a net inflow of capital into the firms.

The picture that emerges from the balance sheet and cash flow analyses is that there seems to be an increasing disengagement from the financial sector pointing to a diminishing role of the financial sector in providing funds for real investment. The changes in the pattern of financing imply that the ubiquitous problems of information asymmetry, agency costs and adverse selection have not improved. This phenomenon is reflected in the decreasing use of external financing and high dividends payouts.

\section{Financial Development in Pakistan}

The landmark year in Pakistan's financial development was 1991 when the country's capital markets were substantially opened to international investors. This was part of a larger set of measures to place the economy on market-based principles and end an era of financial repression. This included measures to liberalize foreign exchange regulations and foreign trade, and to privatize industrial units and banks. Securities markets were deregulated and auction markets for government securities were established. The regulatory controls on corporate public offering of equity and on foreign ownership and underwriting of securities were removed. The tax system was simplified and tax rates were reduced, particularly including exemption of capital gains on equity stock and a tax holiday for selected industrial and financial institutions.

As a result of the post-1991 liberalization, the financial sector saw the establishment of private sector mutual funds, off-shore funds, the creation of Employees' Stock Option Plans, corporate brokerage houses, investment advisory firms (many in collaboration with foreign securities firms) and investment banks. A process of privatization of nationalized commercial banks was initiated during the year 1991-92. A number of 
private commercial banks sprang up creating greater competition within the banking sector. State controls on interest rates charged on bank loans and paid on deposits were removed. The banking sector's balance sheets were strengthened by removing non-performing loans (NPLs) and strengthening the legal framework for the recovery of bank dues. A credit rating agency, the Pakistan Credit Rating Agency, Limited (PACRA), was established in 1994. Another credit rating agency was incorporated in 1997. In 1994-95, a Central Depository Company (CDS) was established to implement an electronic book entry system for securities settlement.

In 1997, the government initiated a Capital Market Development Program (CMDP) with the help of the Asian Development Bank (ADB) to strengthen the capital market. The securities' regulatory body, the Corporate Law Authority, was reconstituted in 1999 as an autonomous Securities and Exchange Commission of Pakistan (SECP). The governance structure of stock exchanges was improved and its regulatory powers were enhanced. Towards the turn of the century, the policy emphasis shifted towards deepening and broadening the markets with the initiation of the Financial (Non-bank) Markets and Governance Program (FMGP) financed by the ADP. The 2000s saw continued broadening and deepening of financial markets through market-based financial instruments and institutions.

Since the market liberation measures of 1991, the equity market in Pakistan has undergone substantial structural changes and growth. Market capitalization, as a percentage of GDP, was only 6.5 percent in 1989, and rose to 23.9 percent by 1993 post-liberalization. The following years have seen a period of steady and strong growth pushing the capitalization ratio to 42.0 at the end of 2005. In the post-2001 period, continued privatization and liberalization policies, together with regulatory and structural reforms, have led to further maturation of the capital markets. The market capitalization was largely boosted by the listing of a number of large stateowned enterprises (SOEs), whose privatization drove market growth. Domestic institutional investors, such as mutual funds and insurance companies, also increased engagement in the capital markets, though the individual investors account for the bulk of exchange trading. The investor base has also expanded due to interest by foreign portfolio investors.

Despite the series of reforms and structural developments, capital market instruments still play a minor role in mobilizing primary financing to the real sector. In 2005 capital raised by corporations and financial institutions through equity and bond issues totaled only 0.3 percent of GDP. Pakistan lags behind other emerging markets in resource mobilization issues 
of new equity through the capital market. Similarly, bond market issues in Pakistan compared to other emerging markets are almost non-existent. The market for derivative instruments also has not developed. The stock market lacks breadth, as well as depth. The 10 largest stocks accounted for 55 percent of the total market capitalization in 2007. Trading of stocks is likewise highly concentrated. Free float is also rather limited; an average of only 20 of the shares of the listed companies are available for trading, resulting in relatively low market liquidity. This, coupled with a high turnover, paints a picture of a highly speculative market.

According to Asian Development Bank report (ADB, 2007), the key issues of concern, among others, are high equity market volatility, small public float (shares available for trading) and weak securities market legislation. The ADB report also noted that the Pakistan stock market's volatility is due partly to a high volume of speculative short-term individual investment in shares and thin public float of the listed companies.

\section{State of Financial Development in Pakistan}

As the financial sector is crucial to any economy's growth, it is important that we monitor and compare its development across economies and over time. The World Bank's Financial Sector Development Indicators (FSDI) project has developed a comprehensive database containing financial sector statistics, which provide analytical tools for enhanced assessment and understanding of financial sector development (Svirydzenka, 2016; World Bank, 2006).

The FSDI database provides numerous variables spanning banking systems, capital markets, non-bank financial sectors, the accessibility to finance and institutional environments. It presents the main dimensions of a financial sector - size, access, efficiency and stability - for the traditional financial sub-sectors, such as banking and capital markets, thus providing practical assessment measures and the basis for assessing a country's overall financial sector, especially when benchmarked against international, regional, or cross-country standards.

The FSDI indicators are grouped into four broad dimensions: (1) size; (2) efficiency; (3) access; and (4) stability. These headline indicators include traditional measures, such as private credit-to-GDP ratios, stock market capitalization-to-GDP ratios, non-performing loans and banking spreads, but also new indicators (collected via surveys), such as ease of access to a bank account by a household and ease of access to financing for a company. 
The benchmarking indicators, combinations of ratios and synthetic statistics allow for the sorting of countries according to these four dimensions.

We examine the FSDI indicators for Pakistan, comparing these with cohort countries (i.e., lower-middle income countries). This analysis is done initially for the overall financial development index, and subsequently, for the financial institutions and financial markets, each having three constituent dimensions (access, depth and efficiency). Figure 2 below shows the Financial Development Index for Pakistan and six other developing countries. Table 3 in the Appendix provides a comparison for Pakistan with other lower-middle countries on the selected statistics underlying the FSDI.

As Figure 2 shows the financial development in Pakistan (thick line) took off around 1995, and, for a number of years, it ranked towards the top of the group, except for India. The country's position continued to improve until about 2007, after which, the index shows rapid decline. According to the latest available data, the country ranks at the bottom of the group, with India's score being twice as high.

\section{Figure 2: Financial Development Index}

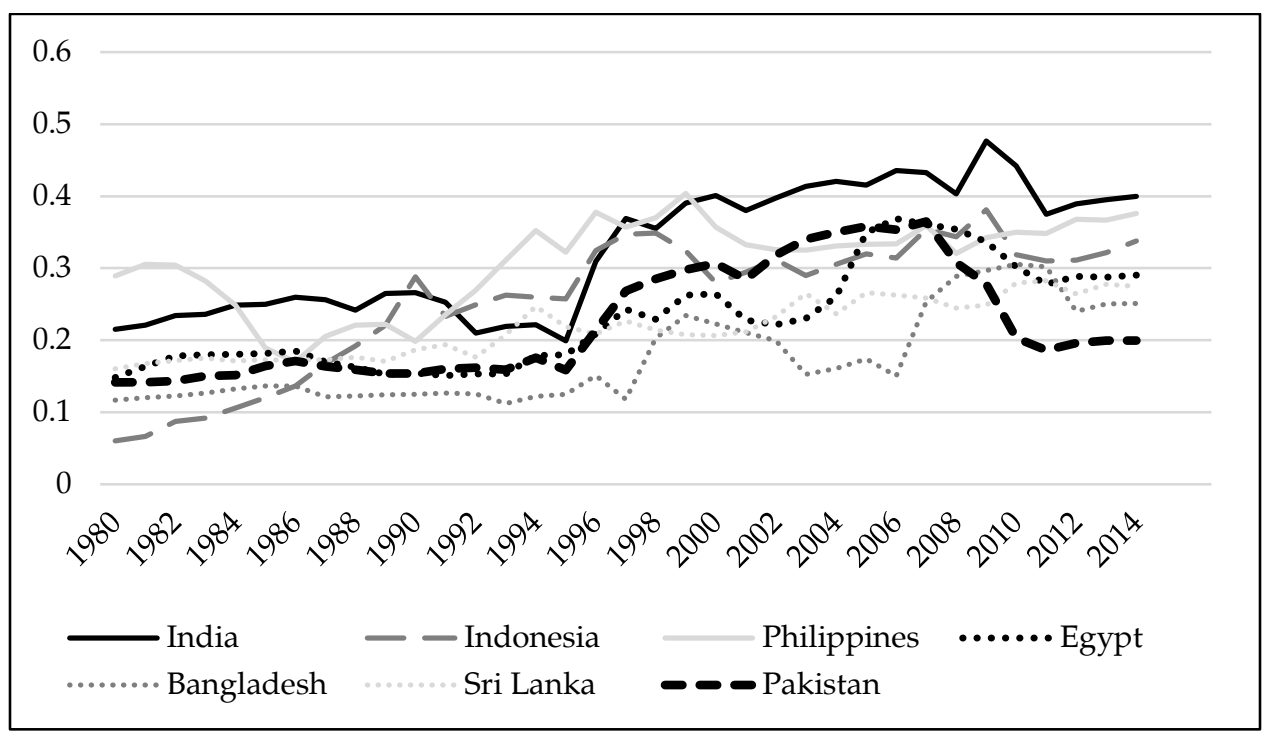

Source: Authors' compilation using data from World Bank (2006).

Figure 3 plots the FSDI's Financial Institutions Index from 19802014 for Pakistan and six other comparable countries. It depicts a picture of varying trends. There is a marked deterioration over the period of 1985- 
1996, which is followed by institutional improvements observed over the next ten years. However, all other countries register steady improvement in institutional development over the last two decades, leaving Pakistan at the bottom of the group.

\section{Figure 3: Financial Institutions Index}

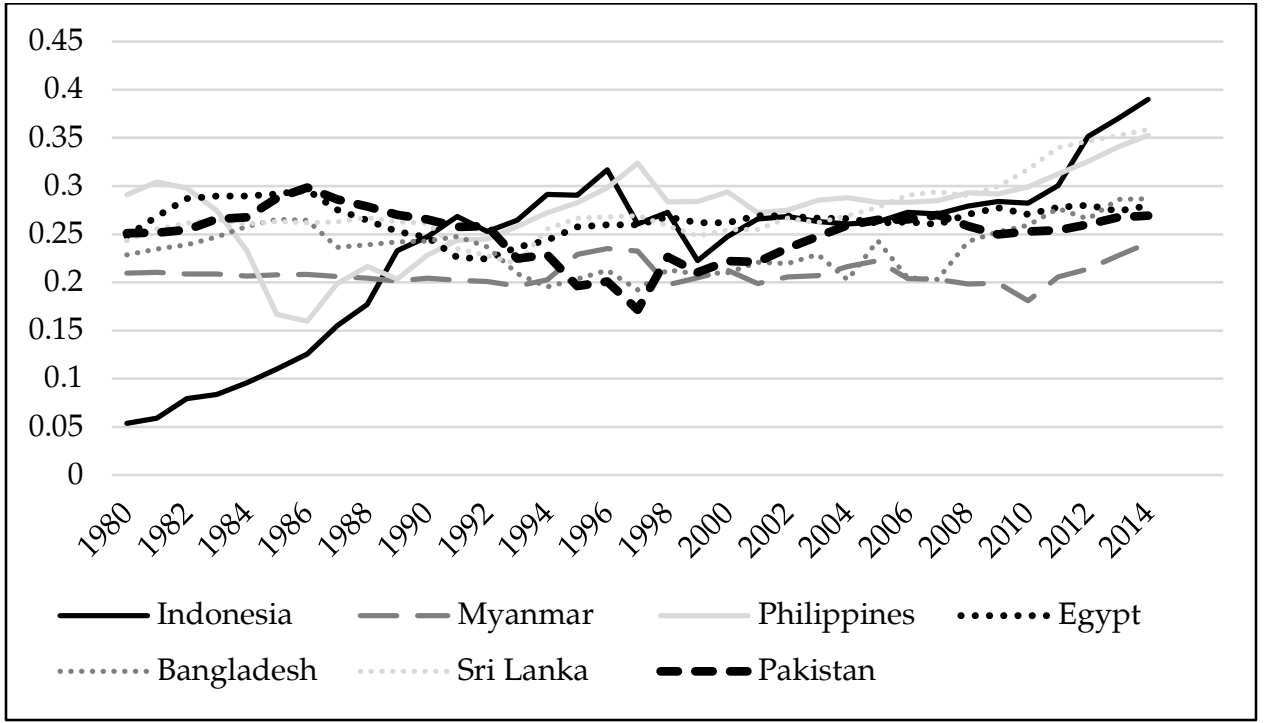

Source: Authors' compilation using data from World Bank (2006).

The Institutional Development Index is further broken into three indices - access, depth and efficiency - each shown in Figures $4,5 \& 6$. The Institutional Access Index (Figure 4) does indicate a steady improvement over the years, but the trend is weaker when compared with the indices for other countries, especially Indonesia and India. 
Figure 4: Financial Institutions Access Index

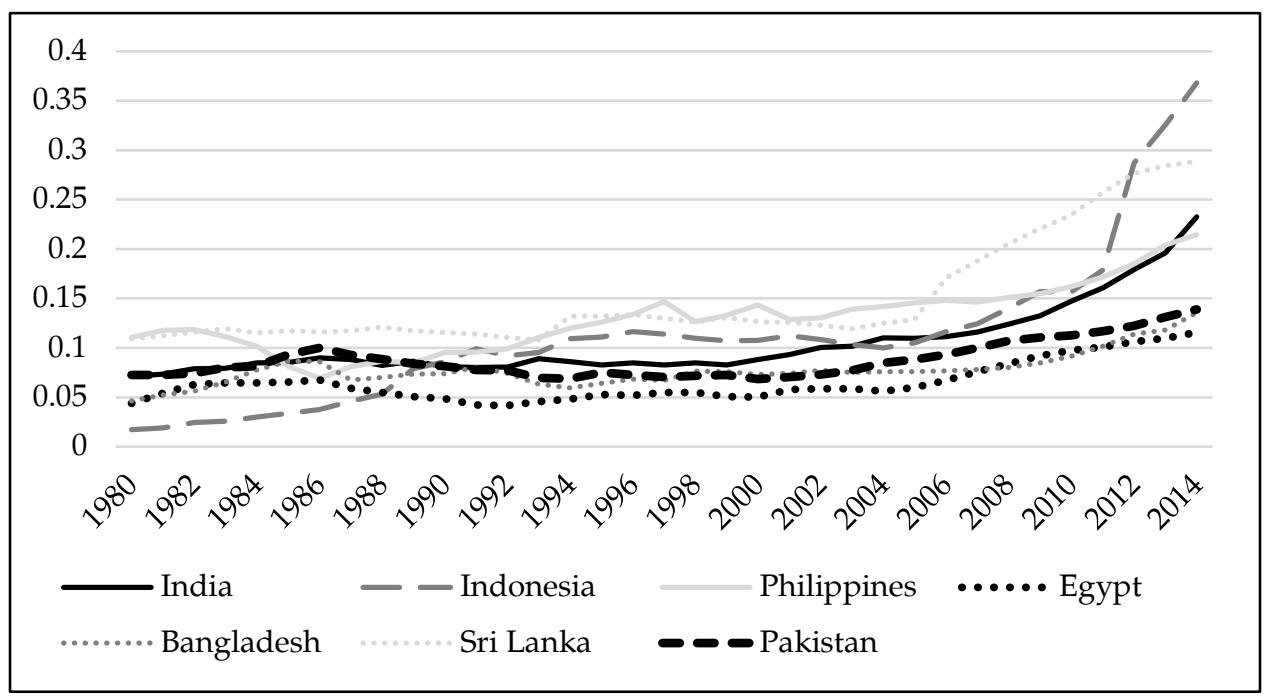

Source: Authors' compilation using data from World Bank (2006).

Pakistan particularly seems to be lagging with respect to the Institutions Depth Index (Figure 5). It has lagged behind the cohort significantly since about the year 2000. There is a significant difference in the ratings in comparison with India.

\section{Figure 5: Financial Institutions Depth Index}

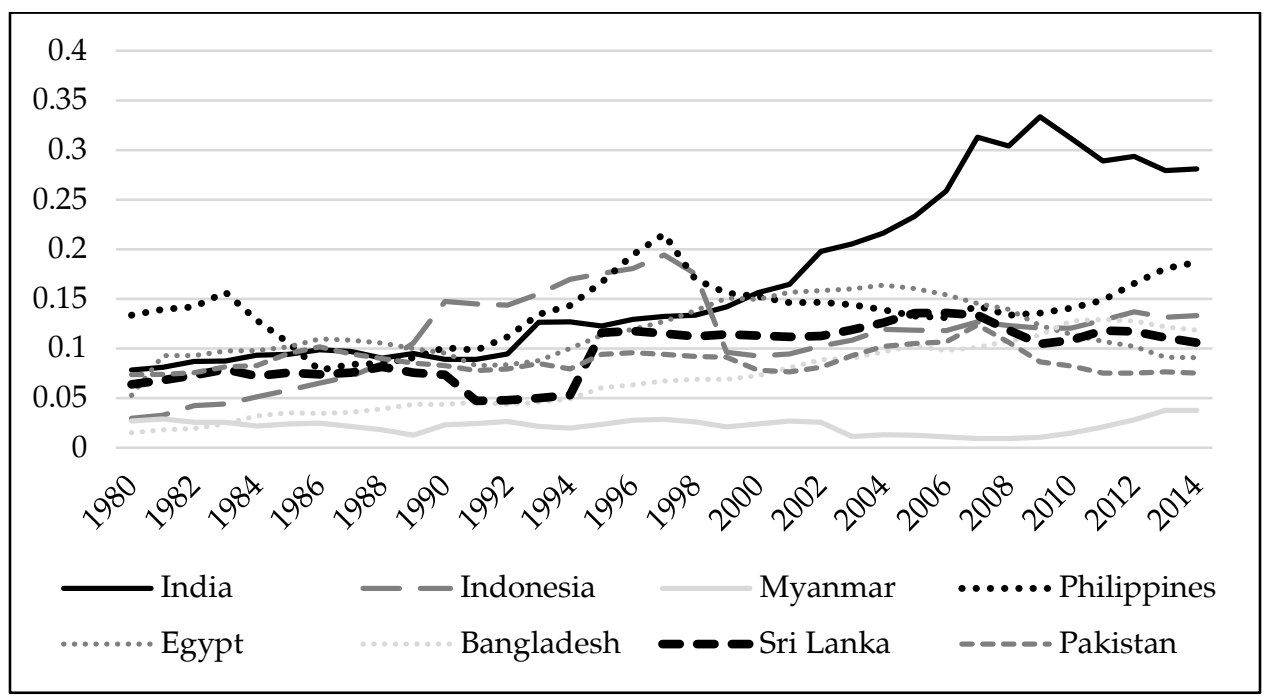

Source: Authors' compilation using data from World Bank (2006). 
The relative score of Pakistan on the Institution Efficiency Index (Figure 6) depicts a better picture. The country is placed in the middle of the reference group. It is noteworthy that India's position is least favorable within this group.

Figure 6: Financial Institutions Efficiency Index

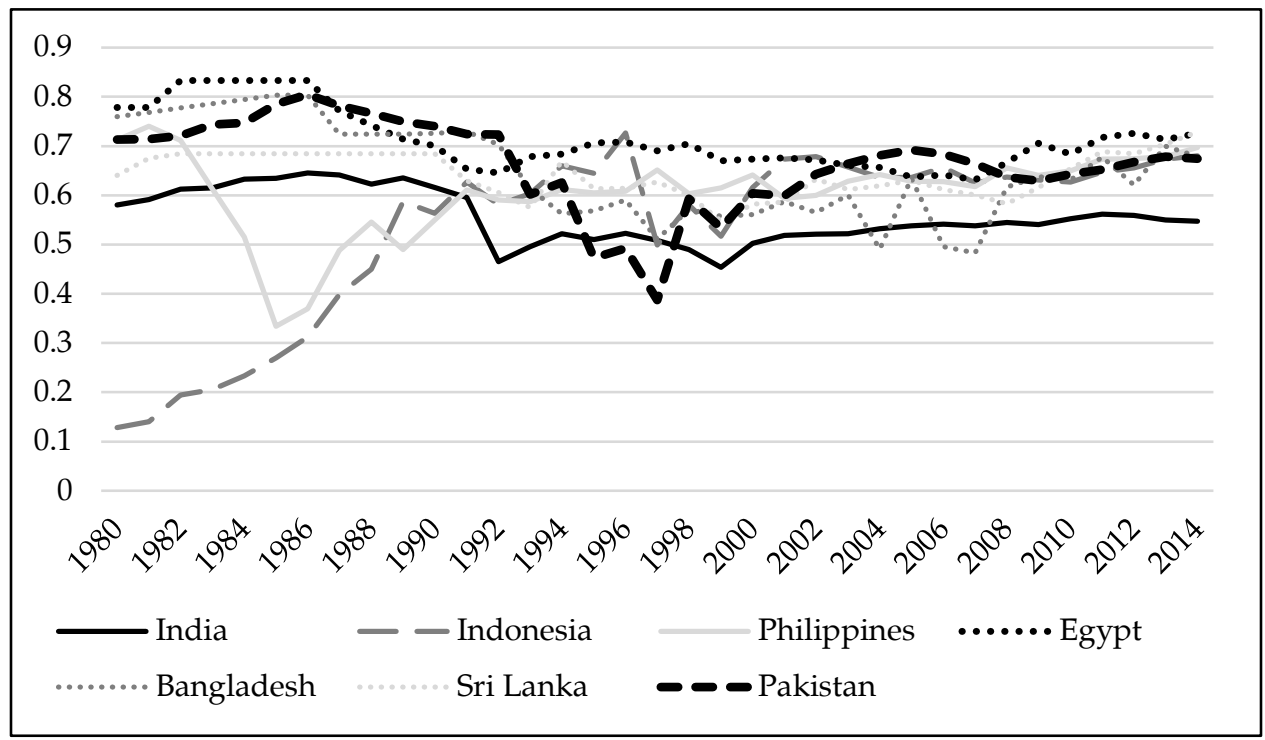

Source: Authors' compilation using data from World Bank (2006).

The next set of indices displays the development of the financial markets (Figures 7 to 10). Figure 7 plots the overall Financial Markets Index over the period 1980-2014. There is a rapid rise in the index concurrent with financial market development in other emerging markets, beginning around the time financial liberalization measures were taken. The index understandably took a nosedive around 2007, when all markets where hit by the Global Financial Crisis. Other countries, however, seem to have either not been affected as much (India or Sri Lanka) or not at all (Bangladesh). Pakistan's capital market seems to have suffered a lasting setback. 


\section{Figure 7: Financial Markets Index}

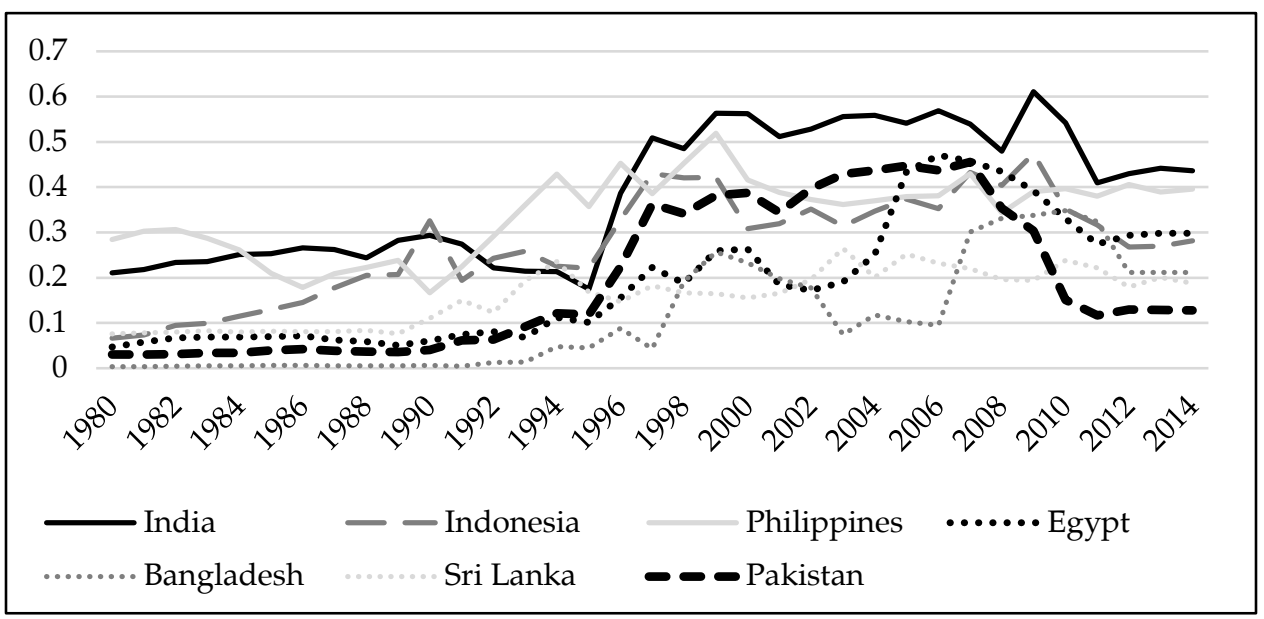

Source: Authors' compilation using data from World Bank (2006).

Regarding market access, the index shown in Figure 8 places Pakistan at the bottom of the group, with scores that are almost zero. This index is based on statistics such as, concentration of top 10 firms (market capitalization), concentration of top 10 firms based on volume, closely held shares in top 10 firms, number of issuers, bonds listed and newly listed and foreign issues in local currencies. In summary, it is a reflection of Pakistani corporations not tapping into the financial markets, which confirms the observation made in the first section.

\section{Figure 8: Financial Markets Access Index}

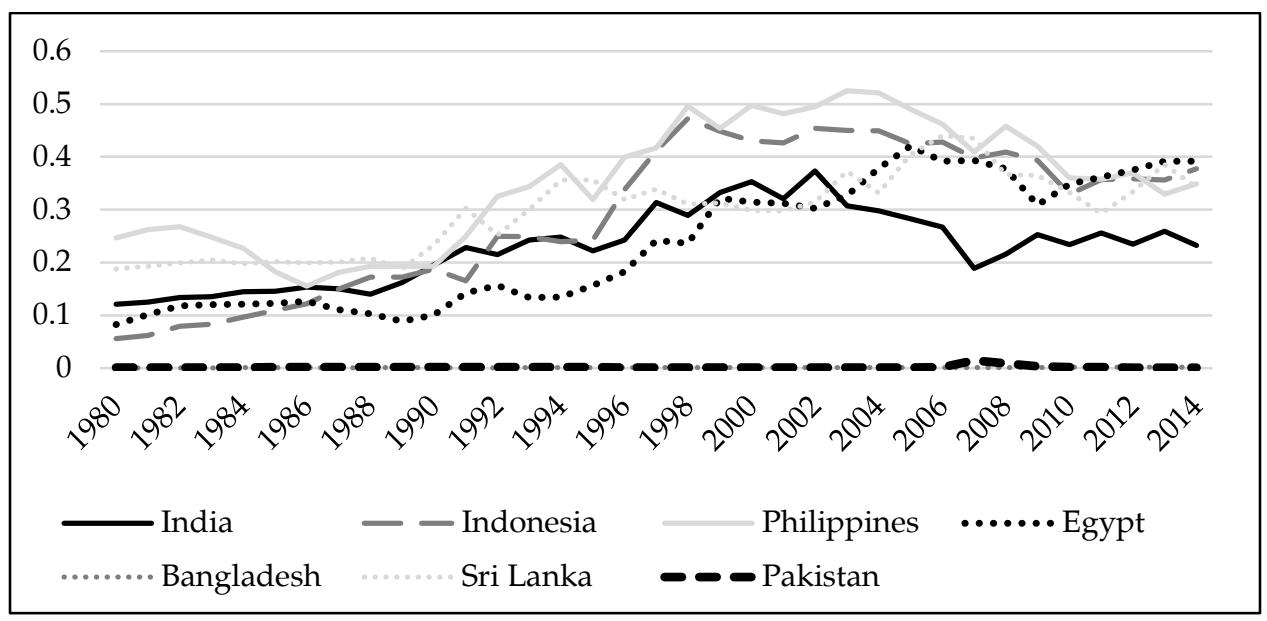

Source: Authors' compilation using data from World Bank (2006). 
The Markets Depth Index (Figure 9) also shows significant drop around 2007. Again, the country does not seem to have recovered from the external shock, unlike the other countries included in the index. It indicates that the markets lack resilience.

Figure 9: Financial Markets Depth Index

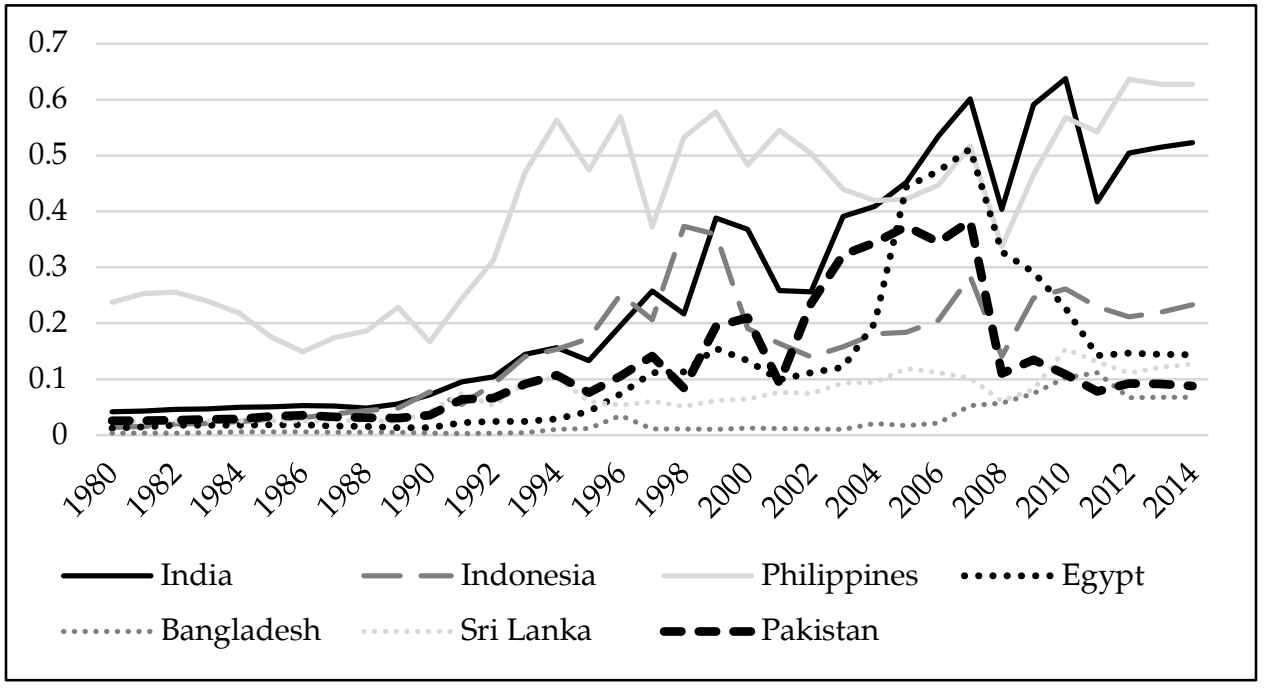

Source: Authors' compilation using data from World Bank (2006).

The Financial Markets Efficiency Index (Figure 10) depicts a contrasting picture. The Index increased sharply around 1995 to its maximum possible value. It dropped precipitously in 2007 and has been rather stable in the middle of the set of indices for the cohort group. It may be that the index is heavily based on trading volume, co-movement of stock returns, and market turnover ratio. All of these may also be indications of excessive trading based on speculation, and may not be significantly correlated with allocative efficiency of the stock market. 
Figure 10: Financial Markets Efficiency Index

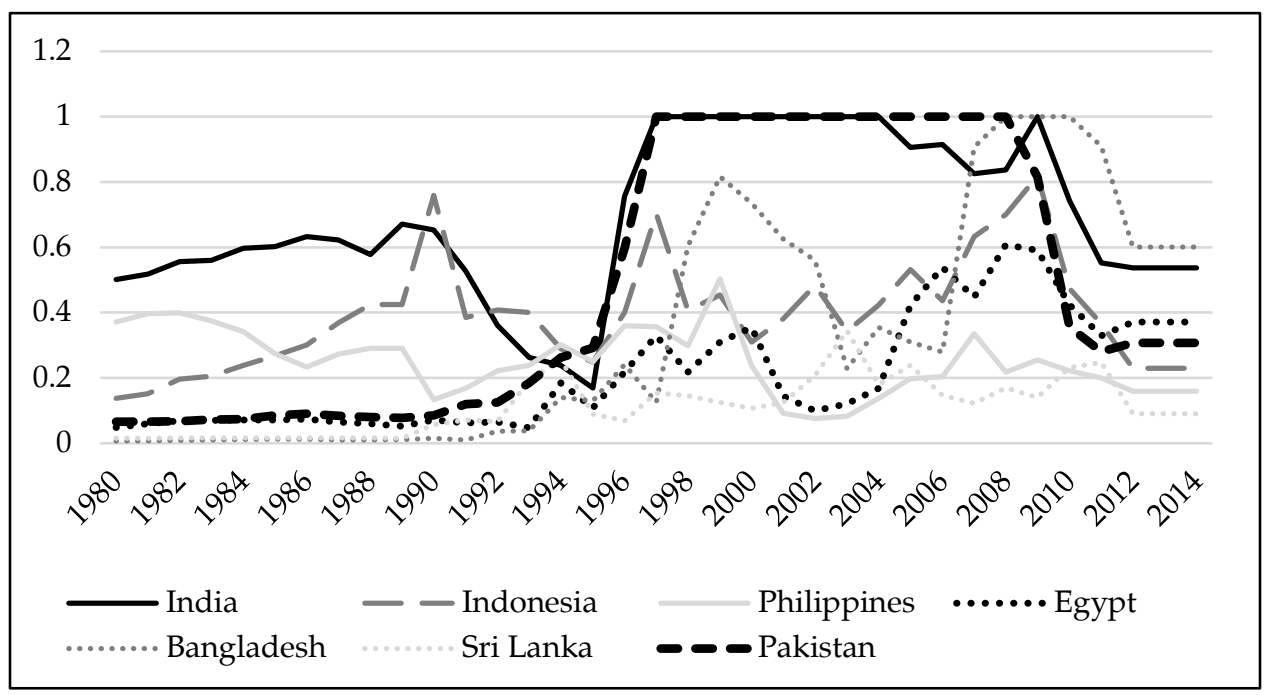

Source: Authors' compilation using data from World Bank (2006).

The overall profile of the Pakistan's financial sector is depicted in Figure 11 below.

\section{Figure 11: Financial Development Indices}

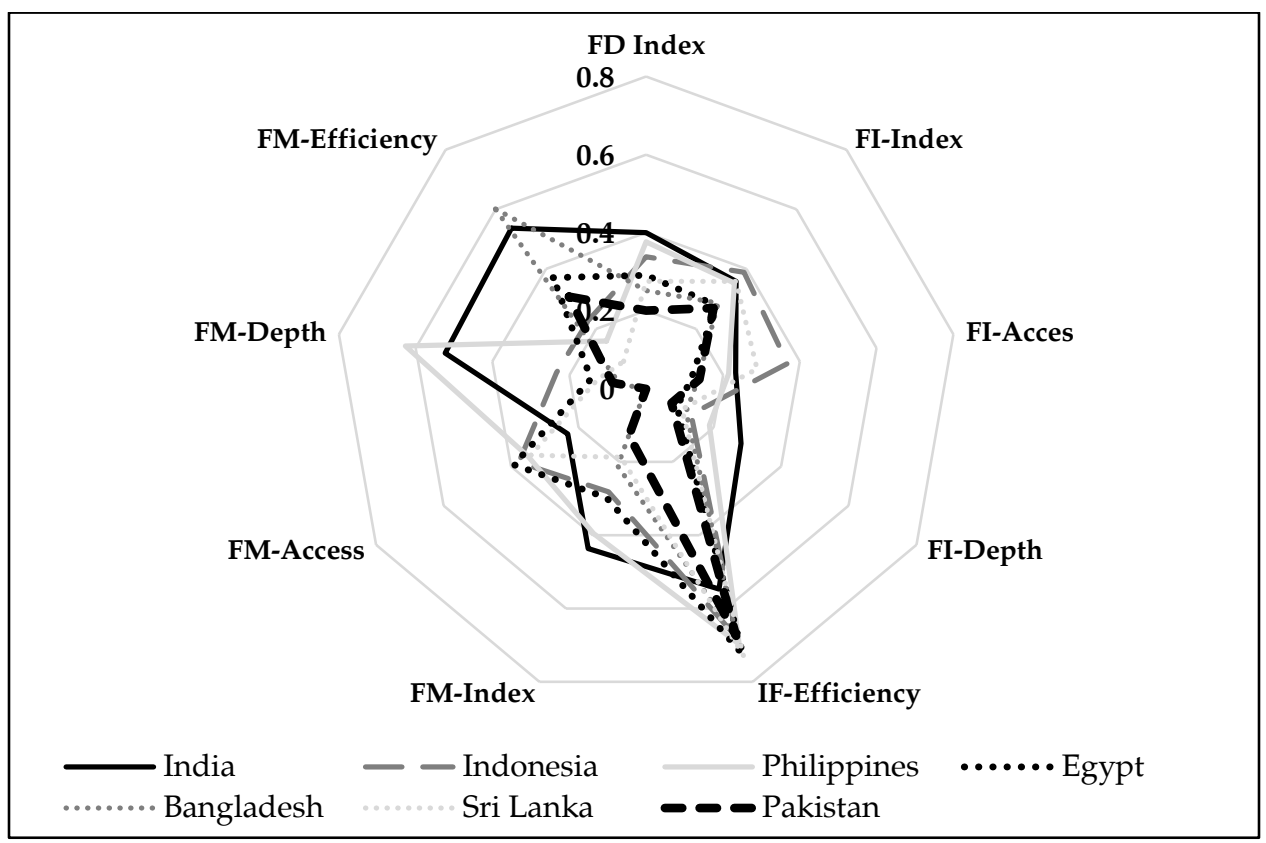

Source: Authors' compilation using data from World Bank (2006). 
The figure shows that the country's financial development stands compares relatively unfavorably with six other countries from the lowermiddle income group. The country fairs unfavorably in all three dimensions of financial development: access, depth and efficiency.

The above comparative analysis was done with respect to the selected sample of countries in terms of the Financial Sector Development Indicators, based on extensive databases, the Global Financial Development Database and the Financial Structure Development Database (Beck, Demirgüç-Kunt \& Levine, 2000). Table 3 in the Appendix presents selected variables from these datasets, allowing for further comparison of Pakistan's financial sector with the lower-middle income countries. A comparison based on detailed statistics allows for more precise focus on the weaknesses in the financial sector that could be targeted for remedial policies. The detailed comparison supports conclusions based on these indices.

Examining the individual indicators (Table 3) we can compare Pakistan's standing vis-a-vis the other countries in the lower-middle income group with respect to the four dimensions of financial development - access, depth, efficiency and stability. Note that the country fares particularly unfavorably with respect to bank access by individuals and firms. For example, the country is placed in the lowest quartile of the indicators in Table 5 below:

\section{Table 5}

\begin{tabular}{llc}
\hline A: Indicator & Percent Rank \\
\hline 1. & Firms with a bank loan or line of credit $(\%)$ & 15 \\
2. & Small firms with a bank loan or line of credit (\%) & 5 \\
3. & Account at a formal financial institution ( $\%$ age 15+) & 2 \\
4. & Saved at a financial institution in the past year (\% age 15+) & 11 \\
\hline
\end{tabular}

Source: Worldwide Governance Indicators (WGI) dataset, the World Bank Group.

Despite that, the indicator labelled "Bank branches per 100,000 adults" has a percent rank of 56, and the use of banking services is rather limited by the firm as shown on Table 6 below: 


\section{Table 6}

\begin{tabular}{llc}
\hline B: & Indicator & Percent Rank \\
\hline 1. & Firms with a checking or savings account (\%) & 10 \\
2. & Firms using banks to finance investments (\%) & 10 \\
3. & Firms using banks to finance working capital (\%) & 15 \\
4. & Private credit by deposit money banks and other financial & 6 \\
& institutions to GDP (\%) & \\
\hline
\end{tabular}

Source: Worldwide Governance Indicators (WGI) dataset, the World Bank Group.

Fifty-seven of the firms are labelled as "not needing a loan", a percent rank of 63. Table 7 indicates that individuals tend to rely on informal credit.

\section{Table 7}

\begin{tabular}{lcc}
\hline C: Indicator & Percent Rank \\
\hline 1. & Loan through store credit in the past year (\% age 15+) & 94 \\
2. & Loan from family or friends in the past year (\% age 15+) & 68 \\
\hline
\end{tabular}

Source: Worldwide Governance Indicators (WGI) dataset, the World Bank Group.

It seems that rather than tapping into banking loan facilities, firms tend to rely on equity capital; as such, "Investments financed by equity or stock sales (\%)" has a percent rank of 84 . Similarly, the private corporate sector is lagging behind in accessing capital through the capital markets. The issuance of new equity (IPOs) is negligible and the corporate bond issuance is even scarcer.

In contrast, the public sector seems to be the dominant player in the financial sector. Pakistan's "Central bank assets to GDP (\%)" is at the 83rd percentile, and the "Outstanding domestic public debt securities to GDP $(\%)^{\prime \prime}$ is at 45 , placing it at the top of the lower-middle income group. In "Credit to government and state owned enterprises to GDP (\%)" Pakistan's percent rank is 97 .

The uneven role of the Pakistan's financial sector is particularly puzzling when considering that it is quite competitive as well as quite profitable. All indicators of competitiveness (i.e., bank concentration, $\mathrm{H}$ statistic, Lerner index, Boone indicator and 5-bank asset concentration) point to a competitive industrial structure. In addition, profitability ratios, bank return on assets (before tax) and bank return on equity (before tax) place the banks at a very high percentile among their cohorts; 72 and 86, 
respectively. They also score around the median in institutional stability (i.e., bank Z-score, bank regulatory capital to risk-weighted assets), though are rated unfavorably in terms of the "bank non-performing loans to gross loans" indicator. This raises the question: What is constraining the banking sector from expanding its services to the non-financial private sector?

The tendency of bank financing towards the public sector may reflect the crowding out phenomenon that occurs when public borrowing stifles private borrowing. However, the banking sector does not seem to be short of loanable funds, as indicated by higher than average deposit-toloan ratios: Bank credit to bank deposits is 49.6 with a percent rank of 9; Financial system deposits to GDP is 30.0 with percent rank of 18 . We also note that the percentage of the firms identifying access to finance as a major constraint is only 13.2 (21st percentile). There also does not seem to be any evidence of "disintermediation" where firms would bypass financial intermediaries to directly access funds from capital markets. Therefore, it may be instructive to examine possible institutional and regulatory impediments in the economic environment, as well as ways the financial sector could be playing a more effective role in promoting real investment. However, the booming equity and the real estate markets indicate a large inflow of capital to these sectors.

\section{An Empirical Exercise - Governance and Financial Development}

In this section we present a brief empirical analysis of the link between effective governance and the development of the financial sector. Our panel data sample consists of 44 countries falling in the lower-middle income group over the period 1996-2014. In order to capture the governance environment in different countries we used aggregate governance indicators developed by the World Bank. The indicators are based on several hundred individual variables measuring perceptions of governance and are drawn from various separate data sources constructed by different organizations. These individual measures of governance are assigned to categories capturing key dimensions of governance and use an unobserved components model to construct six aggregate governance indicators. A detailed discussion can be found in Kaufmann, Kraay and Mastruzzi (2004). The indicators of the six governance dimensions are as follows:

1. Political stability and absence of violence (PV): perceptions of the likelihood that the government will be destabilized or overthrown by unconstitutional or violent means, including political violence and terrorism. 
2. Rule of law (RL): the extent to which agents have confidence in and abide by the rules of society, and in particular the quality of contract enforcement, the police, and the courts, as well as the likelihood of crime and violence.

3. Government effectiveness (GE): the quality of public services, the quality of the civil service and the degree of its independence from political pressures, the quality of policy formulation and implementation, and the credibility of the government's commitment to such policies.

4. Regulatory quality (RQ): the ability of the government to formulate and implement sound policies and regulations which permit and promote private sector development.

5. Voice and accountability (VA): the extent to which a country's citizens are able to participate in selecting their government, as well as freedom of expression, freedom of association, and free media.

6. Control of corruption (CC): control over the extent to which public power is exercised for private gain, including both petty and grand forms of corruption, as well as "capture" of the state by elites and private interests.

In addition to the governance indicators, we used per capita income (GDP) and natural log of Gross Domestic Product (LNGDP) as control variables. Our dependent variables were the Financial Development Index, Financial Institutions Index and the Financial Markets Index.

The results of panel regression are placed in Table 5 in the Appendix. As can be seen from the results, all of the coefficients of the governance indicators were highly statistically significant and were of the expected positive sign. The coefficients on the control variables GDP and Per Capita Income were also significant and with positive signs, as expected. The results provided empirical support for the hypothesis that a country's financial development is linked with its governance environment. The implication is that an improvement in the governance environment would foster financial development, which in turn would nurture economic growth.

For Pakistan there seems to be much room for improvements in the governance environment. As can be seen in Table 8 the country ranks towards the lower quartile of countries across the world. Compared to similar countries, it scores unfavorably, particularly with respect to "Political Stability and Absence of Violence/Terrorism." 


\section{Table 8}

\begin{tabular}{lccccccc}
\hline & \multicolumn{7}{c}{ Percentile Rank - 2016 } \\
\hline Governance Indicators & Pakistan & Indonesia & India & Philippines & Egypt & Bangladesh Sri Lanka \\
\hline Control of Corruption & 19 & 43 & 47 & 34 & 32 & 21 & 48 \\
$\begin{array}{l}\text { Government } \\
\text { Effectiveness }\end{array}$ & 29 & 53 & 57 & 52 & 28 & 25 & 45 \\
$\begin{array}{l}\text { Political Stability and } \\
\text { Absence of }\end{array}$ & 1 & 33 & 14 & 10 & 9 & 10 & 50 \\
$\begin{array}{l}\text { Violence/Terrorism } \\
\text { Regulatory Quality }\end{array}$ & 20 & 39 & 52 & 37 & 36 & 31 & 54 \\
$\begin{array}{l}\text { Rule of Law } \\
\text { Voice and }\end{array}$ & 27 & 50 & 41 & 54 & 18 & 22 & 51 \\
Accountability & 29 & 50 & 59 & 51 & 14 & 31 & 43 \\
\hline
\end{tabular}

Source: Worldwide Governance Indicators (WGI) dataset, the World Bank Group.

\section{A Digression - Some Illustrative Governance Issues}

Heretofore, we have identified weaknesses in the linkages between finance and economic growth, which center on governance and the regulatory environment. We observed that in recent decades, while Pakistan's financial services sector has experienced remarkable growth and structural development, it has not contributed meaningfully towards promoting economic growth in the real sector. Our thesis is that this failure is associated with the worsening of the governance environment in Pakistan. ${ }^{1}$ To bolster this inference, in this section, we will provide some recent examples to highlight the governance issues.

As of writing of this paper, there are ongoing discussions with the IMF for a possible bailout package which would help alleviate the balance of payment problems and dwindling foreign exchange reserves. Pakistan's recent approach to the IMF is the latest in a long series of near-defaults on its foreign debt obligations. It seems that the underlying problem is chronic, which cyclically reemerges as a balance of payments and foreign exchange reserve crisis, and necessitates relief and stabilization packages. While the stabilization programs may have helped to maintain a semblance of macroeconomic stability, they have not helped Pakistan to break the "begging bowl" cycle. Orthodox economic stabilization tools have been used to deal with each episode, but this has led to slowdown in economic and social development. Additionally, each episode was addressed with short-term measures, which did stabilize the economy, but adequate

\footnotetext{
${ }^{1}$ Decay of the institutions of governance is lamented by, among others, by Ishrat Husain in "Governing the Ungovernable," 2018.
} 
follow-through and structural reforms to address the underlying weaknesses were not taken. Unsurprisingly, the economic crises simply manifested themselves again, triggered by the next external shock, or as a consequence of economic mismanagement. The inability to address the problem of chronic twin deficits, the current account and the fiscal deficit, may have its roots in the politico-economy of the decision-making processes. Real change would necessitate generating the political will to take the proverbial bitter pill of radical structural reforms. This political will has been missing due to weak governments and the diverse interests of key elements of the state and sections of society. Though the current crises were visible on the horizon for almost a year, we have yet to see a clear path forward in the government's approach towards handling these issues. Even the accuracy and clarity of economic projections by the Ministry of Finance (MOF) is doubtful (Pasha, 2018).

With hindsight, it is now evident that over the previous five years, the rupee was overvalued by up to 20-25 percent until the end of 2017 and early 2018, when the currency was allowed to depreciate. The abrupt and large drop in the foreign exchange rate was disruptive, amplifying uncertainties and sparking speculative adverse bets against the currency. Perhaps, a gradual increase in interest rates and exchange rate depreciation would have been a better policy option. However, it would have been a difficult decision for any government, particularly one whose credibility and public standing had been damaged. The efforts to improve tax collection, likewise, have been hindered by political considerations.

Independence of the institutions making economic decisions according to their mandates is a pillar of good governance. The State Bank of Pakistan (SBP) started raising the policy rates in 2018, rather belatedly, given the impeding economic challenges and the environment of raising interest rates across the globe. Still, the policy rate appears to be below the level required according to the magnitude of the crisis. It could be that the SBP would have played a more effective role if it enjoyed more independence from the MOF. Similarly, in the case of the Federal Board of Revenue, a separation of the functions of policy and administration would empower it to focus on raising revenue by, for example, undertaking more audits and proactively going after non-filers.

The stock market was deeply impacted by the political and economic uncertainties of 2017 and 2018. In 2017, the KSE-100 index saw its worst annual returns since 2008 and yielded a negative return of 16 percent in 2017. Conversely, 2017 was the best year for Asian markets since 
2009. More remarkably, the volumes shrunk by a quarter over 2016, and continue to drop through 2017, from $\$ 146$ million in the first quarter to less than half at $\$ 70$ million in the final quarter. The macroeconomic policies, in the face of the current balance of payment crisis, have created a level of uncertainty inimical to effective functioning of the financial markets, as well as institutions. Hussain (2018) further points out that the SECP is currently in non-functional as three, of the required five, commissioners' seats are unoccupied. The front line regulator-the Pakistan Stock Exchange (PSX) has also not shown concern regarding financial markets conditions. Foreign investors are particularly sensitive to the exchange rate risk and have tended to exit the market under the uncertainties around the resolution of the balance of payments crisis. It is reported that the outflow from the stock market in the July-September 2018 period amounted to $\$ 186$ million, which was partly responsible for the upheaval in the country's equity market (Hussain, 2018). Improvements in governance at the macroeconomic level would certainly create the environment conducive for better functioning and growth of the financial sector.

There is also room to improve governance at the level of financial institutions and regulatory bodies. Macroeconomic uncertainties have kept the investor base narrow, and have simultaneously discouraged corporations from tapping into the stock market to raise equity. ${ }^{2}$ Thus, the financial markets are unable to fully contribute towards capital formation and economic development in Pakistan. In addition to the high market volatility, there is a general impression that it is a manipulated and unfair playing field. Thus, the retail investors trade mostly on speculation. There is a number of steps that can be taken at the exchange level to address this issue. For example, investor protection - assuring investors that their capital is safe with the PSX stock broker - needs to be improved. As Richard Morin, CEO of the PSX points out, "In the past 20 years, Pakistan has had an average of two broker bankruptcies every year. That is far higher than most markets," Richard Morin, CEO of PSX, quoted by Business Recorder (Business Recorder, 2018).

The exchange also needs to improve its self-regulation to win investors' confidence and create a fair playing field. This year, PSX fired some IT employees for data leaks and some higher management staff were also terminated. It appears that employees were regularly leaking data on major client orders. It is alleged that some investors were also being

\footnotetext{
${ }^{2}$ Retail investors number less than 0.2 percent of the nation's 200 -million plus population, CEO of PSX quoted by Mangi and Kay (2018).
} 
blackmailed through threats to leak their personal data. Insider trading, irregularities and blackmail are also alleged to be the source of the company's change in status as "defaulter." It is suspected that some of the malpractice at the exchange could be due to unwarranted influence of the brokers on the election of directors and staff appointments. If these allegations are true, the fact that PSX is now under Chinese ownership should help to ameliorate the situation.

\section{Summary and Conclusions}

The role of finance in economic growth and development is widely accepted. Therefore, promoting financial development should be a central piece of the economic growth strategy. It involves steps to strengthen institutional infrastructure by building effective legal and regulatory frameworks, and adopting best accounting and auditing standards and practices. There is a strong link between the governance environment and development of financial markets and institutions. We have suggested that the linkage runs from the governance and regulatory environment to the lessening of market imperfections and to a more effective role of the financial sector. Hence, public policies should prioritize measures to strengthen rule of law (particularly, enforceability of contracts), effectiveness of government, and regulatory quality, while enhancing control on corruption. Most importantly, in the context of Pakistan, improving political stability and control over violence/terrorism needs to be a top priority.

Even though in recent decades Pakistan's financial services sector has experienced remarkable growth and structural development, it has not contributed meaningfully towards promoting economic growth in the real sector. Our analysis of the financing pattern of the corporate sector suggests that there seems to be an increasing disengagement from the financial sector pointing to its diminishing role in providing funds for real investment. It implies that the problems of information asymmetry, agency costs and adverse selection have become worse in recent years. We infer that this phenomenon is associated with the worsening of the governance environment in Pakistan.

Indeed, the country's governance and regulatory indicators do not compare favorably with other developing countries. Additionally, the development of Pakistan's financial markets and institutions does not fare well in comparison to a cohort of developing countries. The weakness in the linkage between finance and economic growth seems to stem from a 
weakness in the governance environment. The weaknesses in the country's governance are empirically documented in studies such as Khawja and Mian (2005a and 2005b), Shahzad (2018), and Uppal and Mangla (2011).

Therefore, the foremost challenge Pakistan faces in encouraging its financial services sector to become an effective driver of economic growth is to strengthen the country's governance and regulatory framework. There seems to be much room for improvement, particularly with respect to indicators of political stability and absence of violence. 


\section{References}

Beck, T., Demirgüç-Kunt, A. \& Levine, R. (2000). A new database on financial development and structure. World Bank Economic Review, 14, 597-605.

BR Research (2018, March 6). Spring-clean at the PSX. Business Recorder.

BR Research (2018, June 1). We need to have debate on broking models in Pakistan. Business Recorder.

Burger, J. D. \& Warnock, F.E. (2006). Local currency bond markets. IMF Staff Papers, 53, Special Issue.

Cecchetti, S. G. \& Kharroubi, E. (2015). Why does financial sector growth crowd out real economic growth?. BIS Working Papers, No. 490, Monetary and Economic Department, February 2015.

Cournède, B. and Denk, O. (2015). Finance and economic growth in OECD and G20 countries. OECD Economics Department Working Papers, No. 1223, OECD Publishing, Paris.

Durusu-Ciftci, Dilek, Ispir, M. S. \& Yetkiner, H. (2017). Financial development and economic growth: Some theory and more evidence. Journal of Policy Modeling, 39, 290-306.

Estrada, G., Park, D., \& Ramayandi, A. (2010). Financial development and economic growth in developing Asia. ADB Economics Working Paper Series, No. 233.

Group of Thirty (2013). Long-term finance and economic growth: A report of the working group on long-term finance, Washington, D.C.

Gurley, J.G., Shaw, E.S. (1955). Financial aspects of economic development. American Economic Review, 45, 515-538.

Husain, I. (2018). Governing the ungovernable: Institutional reforms for democratic governance. Oxford University Press, USA.

Hussain, D. (2018, October 22). All the ways we can rescue the PSX. Dawn.

Hussain, D. (2018, October 29). As the bulls prepare to run. Dawn. 
Hussain, D. (2018, November 5) The reckless and the cautious at the PSX. Dawn.

Kaufmann, D., Kraay, A. \& Mastruzzi, M. (2004). Governance matters III: Governance indicators for 1996, 1998, 2000, and 2002. World Bank Economic Review, 18, 253-287.

Khawja, A., Mian, A. (2005a). Unchecked intermediaries: Price manipulation in an emerging stock market. Journal of Financial Economics, 78, 203-241.

Khawja, A., Mian, A. (2005b). Do lenders favor politically connected firms? Rent provision in an emerging financial market. The Quarterly Journal of Economics, 120(4), 1371-1411.

La Porta, R., Lopez-de-Silanes, F., Shleifer, A. \& Vishny, R. (1997). Legal determinants of external finance. Journal of Finance, 52, 1131-1150.

La Porta, R., López-de-Silanes, F., Shleifer, A. \& Vishny, R. (1998). Law and finance. Journal of Political Economy, 106, 1113-1155.

La Porta, R., López-de-Silanes, F., Shleifer, A. \& Vishny, R. (1999). The quality of government. Journal of Law, Economics, and Organization, $15,222-279$.

La Porta, R., López-De-Silanes, F. \& Shleifer, A. (2006). What works in securities laws?. Journal of Finance, 61(1), 1-32.

Levine, R. (1997). Financial development and economic growth: Views and agenda. Journal of Economic Literature, 35, 688-726.

Levine, R. (2005). Finance and growth: Theory and evidence. In P. Aghion \& S.N. Durlauf (eds.), Handbook of Economic Growth, 1,(pp.)Amsterdam, Netherlands: Elsevier.

Lucas, R.E. (1988). On the mechanics of economic development. Journal of Monetary Economics, 22, 3-42.

Mangi, F. \& Kay, C. (2018, February 13). First foreign CEO of Pakistan bourse targets investor safety. Bloomberg. 
Masoud, N. \& Hardaker, G. (2012). The impact of financial development on economic growth: Empirical analysis of emerging market countries. Studies in Economics and Finance, 29(3), 148-173.

McKinnon, R.I. (1973). Money and capital in economic development. Washington, DC: Brookings Institution.

Miller, M.H. (1998). Financial markets and economic growth. Journal of Applied Corporate Finance, 11, 8-14.

North, D. (1981). Structure and change in economic history. New York: Norton.

Pasha, H. (2018, November 6). SBP projections for 2018-19. Business Recorder.

Robinson, J. (1952). The generalization of the general theory, In: The rate of interest and other essays. London: MacMillan.

Shahzad, A. (2018). Capital account liberalisation and development in Pakistan (MPhil Thesis). Lahore School of Economics.

Svirydzenka, K. (2016). Introducing a New Broad-based Index of Financial Development. International Monetary Fund, Washington, DC.

Thiel, M. (2001). Finance and economic growth-a review of theory and the available evidence (No. 158). Directorate General Economic and Financial Affairs (DG ECFIN), European Commission.

Uppal, J.Y. (2007) Role of securities law in the development of domestic corporate bond markets. State Bank of Pakistan Research Bulletin, 3(1), 75-88.

Uppal, J.Y. (2011). Government budget deficit and development of bond market in Pakistan: Issues and challenges. The Lahore Journal of Economics, 16(SE), 159-198.

Uppal, J.Y. \& Mangla, I.U. (2006). Market volatility, manipulation, and regulatory response: A comparative study of Bombay and Karachi stock markets. The Pakistan Development Review, 45(4, II), 1071-1083.

World Bank (2006), Financial sector development indicators: Comprehensive assessment through enhanced information capacity. Washington, DC: World Bank. 
World Bank (2017) World development report 2017: Governance and the law. Washington, DC: World Bank.

Yongseok S. (2013). Financial markets: An engine for economic growth. The Regional Economist (July).

Zhang, J., Wang, L., \& Wang, S. (2012). Financial development and economic growth: Recent evidence from China. Journal of Comparative Economics, 40(3), 393-412. 
Appendix

Table 3: Global Financial Development Data - Lower Middle Income Countries-2015

\begin{tabular}{|c|c|c|c|c|c|c|c|c|c|c|c|}
\hline \multirow{2}{*}{\multicolumn{2}{|c|}{ No Code }} & \multirow[b]{2}{*}{ Indicator name } & \multicolumn{6}{|c|}{ Lower-Middle Income Countries } & \multicolumn{3}{|c|}{ Pakistan } \\
\hline & & & Year & \multicolumn{3}{|c|}{ Count Average Median } & Max & Min & Score & Rank & \multirow{2}{*}{$\begin{array}{c}\begin{array}{c}\% \\
\text { Rank }\end{array} \\
0.22\end{array}$} \\
\hline 1 & AI & Bank accounts per 1,000 adults & 2015 & 28 & 617.80 & 518.02 & 1864.16 & 111.11 & 336.13 & 22 & \\
\hline 2 & $\mathrm{AI}$ & Bank branches per 100,000 adults & 2015 & 45 & 13.85 & 8.37 & 70.44 & 0.56 & 10.04 & 20 & 0.56 \\
\hline 3 & $\mathrm{AI}$ & Firms with a bank loan or line of credit (\%) & 2013 & 20 & 28.69 & 27.80 & 66.80 & 4.70 & 6.70 & 17 & 0.15 \\
\hline 4 & $\mathrm{AI}$ & Small firms with a bank loan or line of credit (\%) & 2013 & 20 & 23.99 & 24.10 & 56.00 & 1.90 & 3.40 & 19 & 0.05 \\
\hline 5 & $\mathrm{AI}$ & Account at a formal financial institution (\%age $15+$ ) & 2014 & 36 & 30.99 & 28.60 & 91.82 & 6.45 & 8.71 & 35 & 0.02 \\
\hline 6 & $\mathrm{AI}$ & Saved at a financial institution in the past year (\%age $15+$ ) & 2014 & 36 & 12.46 & 10.05 & 33.21 & 0.86 & 3.28 & 32 & 0.11 \\
\hline 7 & AI & Saved any money in the past year (\%age 15+) & 2014 & 36 & 47.13 & 44.66 & 76.06 & 20.64 & 31.56 & 30 & 0.17 \\
\hline 8 & AI & Saved using a savings club in the past year (\%age $15+)$ & 2014 & 36 & 12.49 & 10.14 & 39.94 & 1.11 & 11.40 & 17 & 0.54 \\
\hline 9 & AI & Loan from a private lender in the past year (\%age $15+)$ & 2014 & 36 & 5.15 & 3.45 & 18.23 & 0.81 & 5.29 & 12 & 0.68 \\
\hline 10 & AI & Loan through store credit in the past year (\%age 15+) & 2014 & 35 & 9.96 & 6.13 & 36.53 & 1.50 & 25.05 & 3 & 0.94 \\
\hline 11 & AI & Loan from family or friends in the past year (\%age $15+)$ & 2014 & 36 & 27.88 & 25.43 & 60.47 & 9.00 & 33.96 & 12 & 0.68 \\
\hline 12 & AI & Credit card (\%age 15+) & 2014 & 36 & 3.81 & 2.35 & 27.50 & 0.00 & 0.13 & 35 & 0.02 \\
\hline 13 & AI & Debit card (\%age 15+) & 2014 & 36 & 17.06 & 13.25 & 65.72 & 1.70 & 2.94 & 34 & 0.05 \\
\hline 14 & $\mathrm{Al}$ & Mobile phone used to pay bills (\%age $15+$ ) & 2012 & 52 & 17.84 & 11.55 & 92.48 & 0.09 & 5.47 & 41 & 0.21 \\
\hline 15 & AI & ATMs per 100,000 adults & 2015 & 46 & 23.78 & 21.05 & 86.69 & 1.90 & 8.79 & 38 & 0.17 \\
\hline 16 & $\mathrm{AI}$ & Firms with a checking or saving & 2013 & 20 & 82.61 & 91.45 & 98.20 & 35.00 & 58.10 & 18 & 0.10 \\
\hline 17 & AI & Firms using banks to finance investments (\%) & 2013 & 20 & 19.30 & 19.10 & 43.20 & 3.80 & 8.10 & 18 & 0.10 \\
\hline 18 & $\mathrm{AI}$ & Firms using banks to finance working capital (\%) & 2013 & 20 & 24.82 & 24.25 & 56.10 & 3.60 & 8.60 & 17 & 0.15 \\
\hline 19 & $\mathrm{AI}$ & Loans requiring collateral (\%) & 2013 & 20 & 85.18 & 88.20 & 99.50 & 56.40 & 64.00 & 19 & 0.05 \\
\hline 20 & $\mathrm{AI}$ & Value of collateral needed for a loan (\% of the loan amount) & 2013 & 20 & 217.53 & 226.60 & 299.301 & 130.80 & 153.40 & 19 & 0.05 \\
\hline 21 & AI & Firms not needing a loan (\%) & 2013 & 20 & 52.01 & 48.20 & 74.70 & 22.50 & 57.00 & 8 & 0.63 \\
\hline 22 & AI & cent loan application was rejected (\%) & 2013 & 20 & 11.64 & 8.55 & 42.20 & 0.00 & 13.50 & 6 & 0.73 \\
\hline 23 & $\mathrm{AI}$ & Investments financed by banks (\%) & 2013 & 20 & 10.28 & 10.25 & 23.90 & 1.20 & 2.00 & 19 & 0.05 \\
\hline 24 & AI & Working capital financed by banks (\%) & 2013 & 20 & 9.84 & 9.95 & 20.60 & 1.20 & 2.50 & 17 & 0.15 \\
\hline
\end{tabular}




\begin{tabular}{|c|c|c|c|c|c|c|c|c|c|c|c|}
\hline \multirow{2}{*}{\multicolumn{2}{|c|}{ No Code }} & \multirow[b]{2}{*}{ Indicator name } & \multicolumn{6}{|c|}{ Lower-Middle Income Countries } & \multicolumn{3}{|c|}{ Pakistan } \\
\hline & & & \multicolumn{4}{|c|}{ Year Count Average Median } & \multirow{2}{*}{\begin{tabular}{|l|} 
Max \\
62.20
\end{tabular}} & \multirow{2}{*}{$\begin{array}{r}\text { Min } \\
5.20 \\
\end{array}$} & \multirow{2}{*}{\begin{tabular}{|c|} 
Score \\
13.20 \\
\end{tabular}} & \multirow{2}{*}{$\begin{array}{c}\text { Rank } \\
16 \\
\end{array}$} & \multirow{2}{*}{$\begin{array}{c}\begin{array}{c}\% \\
\text { Rank }\end{array} \\
0.21\end{array}$} \\
\hline 25 & AI & Firms identifying access to finance as a major constraint (\%) & 2013 & 20 & 26.19 & 24.90 & & & & & \\
\hline 26 & $\mathrm{AM}$ & Investments financed by equity or stock sales (\%) & 2013 & 20 & 5.46 & 5.45 & 14.20 & 0.30 & 8.50 & 4 & 0.84 \\
\hline 27 & DI & Private credit by deposit money banks to GDP (\%) & 2015 & 45 & 35.09 & 31.53 & 102.79 & 6.70 & 14.90 & 41 & 0.09 \\
\hline 28 & DI & Deposit money banks' assets to GDP (\%) & 015 & 45 & 43.68 & 39.90 & 118.06 & 9.88 & 39.90 & 23 & 0.50 \\
\hline 29 & DI & Nonbank financial institutions' assets to GDP (\%) & 013 & 18 & 7.85 & 3.54 & 28.56 & 0.80 & 0.00 & na & na \\
\hline 30 & DI & $\begin{array}{l}\text { Deposit money bank assets to deposit money bank assets and } \\
\text { central bank assets }(\%)\end{array}$ & 2015 & 44 & 89.92 & 94.52 & 99.95 & 59.08 & 81.13 & 36 & 0.18 \\
\hline 31 & DI & Liquid liabilities to GDP (\%) & 015 & 45 & 48.69 & 39.77 & 128.38 & 14.81 & 39.46 & 24 & 0.47 \\
\hline 32 & DI & DP (\%) & 15 & 44 & 4. & 2.46 & 26.28 & 0.02 & 9.28 & 8 & 0.83 \\
\hline 33 & DI & Muto & 015 & 3 & 3.54 & 1.72 & 7.33 & 1.56 & 1.56 & 3 & 0.00 \\
\hline 34 & DI & Finar & 015 & 45 & 41.41 & 39.18 & 89.84 & 10.04 & 30.05 & 32 & 0.29 \\
\hline 35 & DI & Life it & 014 & 32 & 0 & 0.31 & 2.51 & 0.00 & 0.49 & 12 & 0.64 \\
\hline 36 & DI & Non & 14 & 36 & 0.62 & 0.52 & 1.69 & 0.05 & 0.22 & 30 & 0.17 \\
\hline 37 & DI & Insur & 014 & 18 & 3.71 & 2.59 & 16.79 & 0.57 & 1.10 & 15 & 0.17 \\
\hline 38 & DI & $\begin{array}{l}\text { Private credit by deposit money banks and other financial } \\
\text { institutions to GDP (\%) }\end{array}$ & 2015 & 45 & 37.31 & 33.49 & 102.79 & 6.70 & 14.90 & 42 & 0.06 \\
\hline 39 & & asion fund a $\mathrm{c}$ & & 10 & & 3.37 & 32.31 & 0.04 & 0.04 & 10 & 0.00 \\
\hline 40 & DI & $\mathrm{Dc}$ & 15 & 45 & 38.40 & 34.89 & 111.93 & 7.14 & 15.38 & 41 & 0.09 \\
\hline 41 & DM & Stock & 013 & 10 & 37.86 & 31.50 & 81.92 & 13.24 & 0.00 & na & na \\
\hline 42 & $\mathrm{DM}$ & 1 value traded to GDP $(\%)$ & 2014 & 14 & 5.91 & 2.46 & 30.93 & 0.13 & 0.22 & 13 & 0.07 \\
\hline 43 & DM & Outstanding domestic private debt securitie & 2013 & 2 & 1.28 & 1.28 & 2.09 & 0.46 & 0.00 & na & na \\
\hline 44 & DM & Outstanding domestic public debt securities to GDP (\%) & 2015 & 4 & 28.91 & 28.99 & 45.44 & 12.24 & 45.44 & 1 & 1.00 \\
\hline 45 & DM & ational private debt $\mathrm{s}$ & 2013 & 12 & 3.60 & 2.05 & 14.19 & 0.48 & 0.00 & na & na \\
\hline 46 & DM & Outstanding international public debt securities to GDP (\%) & 2015 & 17 & 7.03 & 4.49 & 21.57 & 0.38 & 1.87 & 14 & 0.18 \\
\hline 47 & DM & Outstanding total international debt securities / GDP (\%) & 2015 & 17 & 10.33 & 10.07 & 36.59 & 1.71 & 1.87 & 15 & 0.12 \\
\hline 48 & DM & Gross portfolio equity liabilities to GDP (\%) & 2015 & 22 & 2.80 & 1.21 & 15.19 & 0.00 & 2.15 & 8 & 0.66 \\
\hline 49 & DM & Gross portfolio equity assets to GDP (\%) & 2015 & 19 & 1.51 & 0.20 & 18.12 & 0.01 & 0.05 & 16 & 0.16 \\
\hline 50 & DM & Gross portfolio debt liabilities to GDP (\%) & 2015 & 19 & 7.44 & 4.63 & 27.57 & 0.00 & 1.90 & 12 & 0.38 \\
\hline & DM & Gross portfolio debt assets to GDP (\%) & 2015 & 24 & 1.53 & 0.53 & 9.32 & 0.00 & 0.07 & 19 & 0.21 \\
\hline
\end{tabular}




\begin{tabular}{|c|c|c|c|c|c|c|c|c|c|c|}
\hline \multirow[b]{2}{*}{ No Code } & \multirow[b]{2}{*}{ Indicator name } & \multicolumn{6}{|c|}{ Lower-Middle Income Countries } & \multicolumn{3}{|c|}{ Pakistan } \\
\hline & & $\overline{\text { Year }}$ & Coun & Average & Median & Max & Min & Score & Rank & $\%$ \\
\hline $52 \mathrm{DM}$ & Syndicated loan issuance volume to GDP (\%) & 2015 & 22 & 3.07 & 0.96 & 39.24 & 0.11 & 0.79 & 13 & 0.42 \\
\hline $53 \mathrm{DM}$ & Corporate bond issuance volume to GDP (\%) & 2013 & 9 & 0.88 & 0.84 & 1.77 & 0.11 & 0.00 & na & na \\
\hline $54 \mathrm{DM}$ & Syndicated loan average maturity (years) & 2014 & 22 & 8.28 & 6.76 & 20.01 & 0.94 & 3.00 & 18 & 0.14 \\
\hline 55 EI & Bank net interest margin $(\%)$ & 2015 & 43 & 4.81 & 4.36 & 10.92 & 1.46 & 4.07 & 28 & 0.35 \\
\hline $56 \mathrm{EI}$ & Bank lending-deposit spread & 2013 & 36 & 7.60 & 6.88 & 19.48 & 0.45 & 4.81 & 28 & 0.22 \\
\hline $58 \mathrm{EI}$ & Bank noninterest income to total income $(\%)$ & 2015 & 41 & 19.28 & 11.73 & 93.18 & 2.47 & 6.33 & 37 & 0.10 \\
\hline $59 \mathrm{EI}$ & Bank overhead costs to total assets (\%) & 2015 & 44 & 5.35 & 2.97 & 89.42 & 0.71 & 2.36 & 30 & 0.32 \\
\hline $60 \mathrm{EI}$ & Bank return on assets ( $\%$, after tax) & 2015 & 43 & 1.27 & 1.26 & 4.69 & -4.22 & 1.47 & 16 & 0.64 \\
\hline $61 \mathrm{EI}$ & Bank return on equity $(\%$, after tax $)$ & 2015 & 44 & 11.91 & 11.53 & 29.23 & -18.91 & 15.56 & 14 & 0.69 \\
\hline $62 \mathrm{EI}$ & Bank cost to income ratio (\%) & 2015 & 41 & 77.22 & 75.43 & 155.94 & 20.00 & 62.16 & 31 & 0.25 \\
\hline 63 EI & Credit to government and state owned enterprises to GDP (\%) & 2015 & 42 & 10.02 & 6.69 & 49.14 & 0.04 & 28.15 & 2 & 0.97 \\
\hline 64 EI & Bank return on assets $(\%$, before tax) & 2015 & 44 & 1.15 & 1.81 & 4.69 & -26.51 & 2.46 & 13 & 0.72 \\
\hline 65 EI & Bank return on equity $(\%$, before tax) & 2015 & 44 & 16.84 & 16.15 & 38.41 & -19.36 & 26.12 & 7 & 0.86 \\
\hline 66 EM & Stock market turnover ratio (\%) & 2012 & 37 & 7.66 & 5.44 & 25.70 & 0.53 & 14.47 & 5 & 0.88 \\
\hline 67 SI & Bank Z-score & 2015 & 42 & 14.26 & 11.75 & 53.63 & 2.52 & 11.21 & 22 & 0.48 \\
\hline 68 SI & Bank nonperforming loans to gross loans (\%) & 2015 & 33 & 8.12 & 5.99 & 28.03 & 0.42 & 11.36 & 8 & 0.78 \\
\hline 69 SI & Bank capital to total assets (\%) & 2015 & 31 & 11.64 & 11.31 & 19.59 & 5.43 & 8.42 & 24 & 0.23 \\
\hline $70 \mathrm{SI}$ & Bank credit to bank deposits (\%) & 2015 & 45 & 96.97 & 79.88 & 684.20 & 32.28 & 49.60 & 41 & 0.09 \\
\hline 71 SI & Bank regulatory capital to risk-weighted assets (\%) & 2015 & 33 & 17.89 & 16.18 & 36.70 & 10.15 & 17.34 & 15 & 0.56 \\
\hline 72 SI & Liquid assets to deposits and short-term funding (\%) & 2015 & 45 & 29.73 & 25.57 & 85.04 & 10.96 & 11.84 & 44 & 0.02 \\
\hline $73 \mathrm{SI}$ & Provisions to nonperforming loans (\%) & 2015 & 32 & 66.70 & 60.57 & 243.30 & 23.42 & 84.95 & 5 & 0.87 \\
\hline $74 \mathrm{SM}$ & Stock price volatility & 2015 & 17 & 14.23 & 13.37 & 29.18 & 6.84 & 13.26 & 11 & 0.37 \\
\hline 75 OI & Bank concentration $(\%)$ & 2015 & 36 & 62.93 & 56.99 & 100.00 & 28.48 & 46.09 & 27 & 0.25 \\
\hline 76 OI & Bank deposits to GDP (\%) & 2015 & 45 & 41.36 & 39.18 & 89.84 & 10.04 & 30.05 & 32 & 0.29 \\
\hline 77 OI & H-statistic & 2015 & 27 & 0.54 & 0.54 & 0.97 & 0.12 & 0.74 & 6 & 0.80 \\
\hline 78 OI & Lerner index & 2012 & 34 & 72.26 & 71.52 & 100.00 & 34.52 & 58.91 & 24 & 0.30 \\
\hline 79 OI & Boone indicator & 2015 & 43 & -0.05 & -0.03 & 0.27 & -0.66 & 0.23 & 2 & 0.97 \\
\hline $80 \mathrm{OI}$ & 5-bank asset concentration & 2015 & 31 & 73.36 & 68.91 & 100.00 & 35.93 & 63.22 & 23 & 0.26 \\
\hline $81 \mathrm{OI}$ & Loans from nonresident banks (net) to GDP (\%) & 2014 & 10 & 0.32 & 0.23 & 1.24 & -0.90 & 0.41 & 5 & 0.55 \\
\hline
\end{tabular}




\begin{tabular}{|c|c|c|c|c|c|c|c|c|c|c|}
\hline \multirow[b]{2}{*}{ No Code } & \multirow[b]{2}{*}{ Indicator name } & \multicolumn{6}{|c|}{ Lower-Middle Income Countries } & \multicolumn{3}{|c|}{ Pakistan } \\
\hline & & $\overline{\text { Year }}$ & ount & Average & Median & Max & Min & Score & Rank & $\begin{array}{c}\% \\
\text { Rank }\end{array}$ \\
\hline $82 \mathrm{OI}$ & Loans from nonresident banks (amounts outstanding) to GDP (\%) & 2015 & 18 & 10.18 & 9.30 & 36.66 & 1.76 & 1.87 & 16 & 0.11 \\
\hline $83 \mathrm{OI}$ & $\begin{array}{l}\text { External loans and deposits of reporting banks vis-à-vis the } \\
\text { banking sector ( of domestic bank deposits) }\end{array}$ & 2015 & 43 & 23.03 & 14.39 & 100.95 & 1.80 & 12.50 & 24 & 0.45 \\
\hline $84 \mathrm{OI}$ & $\begin{array}{l}\text { External loans and deposits of reporting banks vis-à-vis the } \\
\text { nonbanking sectors ( of domestic bank deposits) }\end{array}$ & 2015 & 44 & 113.61 & 7.25 & 4491.24 & 0.59 & 3.46 & 32 & 0.27 \\
\hline 85 OI & $\begin{array}{l}\text { External loans and deposits of reporting banks vis-à-vis all sectors } \\
\text { (\% of domestic bank deposits) }\end{array}$ & 2015 & 44 & 142.99 & 23.61 & 4819.92 & 3.81 & 15.96 & 30 & 0.32 \\
\hline 86 OI & Remittance inflows to GDP (\%) & 2015 & 48 & 8.42 & 6.63 & 28.76 & 0.16 & 7.12 & 22 & 0.55 \\
\hline $87 \mathrm{OI}$ & Consolidated foreign claims of BIS reporting banks to GDP (\%) & 2015 & 48 & 35.82 & 11.95 & 1033.59 & 0.22 & 3.95 & 36 & 0.25 \\
\hline 88 OI & Foreign banks among total banks (\%) & 2013 & 32 & 43.47 & 45.00 & 94.00 & 0.00 & 43.00 & 17 & 0.48 \\
\hline 89 OI & Foreign bank assets among total bank assets (\%) & 2013 & 22 & 36.50 & 27.00 & 100.00 & 0.00 & 52.00 & 7 & 0.71 \\
\hline $90 \mathrm{OM}$ & Number of listed companies per $1,000,000$ people & 2014 & 16 & 3.94 & 2.68 & 14.15 & 0.80 & 3.01 & 7 & 0.60 \\
\hline $91 \mathrm{OM}$ & Stock market return (, year-on-year) & 2015 & 17 & -0.39 & -0.01 & 14.83 & -21.50 & 10.64 & 3 & 0.87 \\
\hline
\end{tabular}

Source: World Bank, 2006. 


\section{Table 4: Financial Development Indices and Governance Indicators - Results}

\begin{tabular}{|c|c|c|c|c|c|c|c|c|c|c|c|c|c|c|c|c|c|c|c|c|c|c|c|}
\hline \multicolumn{24}{|c|}{ A) Dependent Variable: Financial Development Index } \\
\hline \multicolumn{4}{|c|}{ Control of Corruption (CC) } & \multicolumn{4}{|c|}{ Government Effectiveness (GE) } & \multicolumn{4}{|c|}{\begin{tabular}{|c|} 
Political Stability and Absence of \\
Violence/Terrorism (PV)
\end{tabular}} & \multicolumn{4}{|c|}{ Rule of Law (RL) } & \multicolumn{4}{|c|}{ Regulatory Quality (RQ) } & \multicolumn{4}{|c|}{ Voice and Accountability (VA) } \\
\hline Variable & eff & t-Stat & Prob. & Variable & eff & Stat & Prob. & Variable & Coeff & t-Stat & Prob. & Vari & Coeff & $\mathrm{t}$-Stat & Prob. & $\mathrm{Va}$ & Coeff & $\mathrm{t}$-Stat & Prob. & Variable & Coeff & Stat & Prob. \\
\hline C & 0.065 & 11531 & 0.000 & GE & & 14.508 & 000 & $\mathrm{PV}$ & 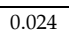 & 5.755 & 0.000 & RL & 0.0 & 14.323 & 0.000 & RQ & 0,047 & 7.735 & 0.000 & VA & 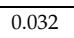 & 37 & 0.000 \\
\hline LNGDP & 0.032 & 25.719 & 0.000 & $\mathrm{~L}$ & 0 & 66 & 0.000 & $\mathrm{DP}$ & 32 & 19.833 & 0. & & $0 . c$ & 27.479 & 0.000 & $\mathrm{LI}$ & 0.024 & 20.324 & 0.000 & LN & 28 & 23.844 & 0.000 \\
\hline PCAP & 0.000 & 2.985 & 0.003 & PCAP & 0 & & 0.000 & PCAP & 0.000 & 4.844 & 0.000 & PCAP & 0.000 & 3.080 & 0.002 & PCAP & 0.000 & 4.699 & 0.000 & PCAP & 0.000 & 5.173 & 0.000 \\
\hline 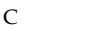 & -0.539 & -19.582 & 0.000 & C & -0.373 & -14.228 & 0.000 & C & -0.578 & -16.392 & 0.000 & C & -0.511 & -19.971 & 0.000 & & -0.379 & -12.788 & 0.000 & & -0.490 & -17.730 & 0.000 \\
\hline \multicolumn{4}{|c|}{ Total panel observations 691} & \multicolumn{4}{|c|}{ Total panel observations 688} & \multicolumn{4}{|c|}{ Total panel observations 685} & \multicolumn{4}{|c|}{ Total panel observations 693} & \multicolumn{4}{|c|}{ Total panel observations 689} & \multicolumn{4}{|c|}{ Total panel observations 693} \\
\hline Adj R-sq & 0.504 & Akaike IC & -2.675 & Adj R-sq & 0.547 & Akaike IC & -2.763 & Adj R-sq & 0.434 & Akaike IC & -2.539 & Adj R-sq & 0.546 & Akaike IC & -2.761 & Adj R-sq & 0.454 & Akaike IC & -2.579 & Adj R-sq & 0.468 & Akaike IC & -2.603 \\
\hline E-stat & 234.4 & Prob F & 0.000 & F-stat & 277.2 & Prob F & 0.000 & F-stat & 175.5 & Prob F & 0.000 & F-stat & 278.4 & Prob F & 0.000 & F-stat & 192.0 & Prob F & 0.000 & F-stat & 204.3 & Prob F & 0.000 \\
\hline
\end{tabular}

\section{B) Dependent Variable: Financial Institutions Index}

\begin{tabular}{|c|c|c|c|c|c|c|c|c|c|c|c|c|c|c|c|c|c|c|c|c|c|c|c|}
\hline \multicolumn{4}{|c|}{ Control of Corruption (CC) } & \multicolumn{4}{|c|}{ Government Effectiveness (GE) } & \multicolumn{4}{|c|}{\begin{tabular}{|c}
$\begin{array}{c}\text { Political Stability and Absence of } \\
\text { Violence/Terrorism (PV) }\end{array}$ \\
\end{tabular}} & \multicolumn{4}{|c|}{ Rule of Law (RL) } & \multicolumn{4}{|c|}{ Regulatory Quality (RQ) } & \multicolumn{4}{|c|}{ Voice and Accountability (VA) } \\
\hline Variable & Coeff & $\mathrm{t}$-Stat & Prob. & Variable & Coeff & $\mathrm{t}$-Stat & Prob. & Variable & Coeff & $\mathrm{t}$-Stat & Prob. & Varia & Coeff & t-Stat & Prob. & Variable & Coeff & t-Stat & Prob. & Variable & Coeff & t-Stat & Prob. \\
\hline$\overline{\mathrm{CC}}$ & 0.063 & 11.755 & 0.000 & GE & 0.067 & 11.847 & 0.000 & PV & 0.030 & 7.739 & 0.000 & RL & 0.041 & 17 & 0.000 & $R Q$ & 0.028 & 4.706 & 0.000 & VA & 0.019 & 5.308 & 0.000 \\
\hline $\mathrm{P}$ & 0.019 & 16 & 0.000 & SDP & 0.0 & & 0.000 & LI & $0 .($ & 13.813 & & LNC & & & 0.000 & GDP & 0. & & 0.000 & GDP & 0.015 & 924 & 0.000 \\
\hline $\mathrm{PC}$ & 0.000 & 15 & 0.000 & & 0. & & & & & & & & & & 0.000 & & & & 0. & $\mathrm{P}$ & 0. & & 00 \\
\hline & -0.237 & -9.072 & 0.000 & & -0.089 & -3.436 & 0.001 & & -0.300 & -9.112 & 0.000 & & -0.197 & -7.438 & 0.000 & C & -0.110 & -3.790 & 0.000 & C & -0.183 & -6.727 & 0.000 \\
\hline \multicolumn{4}{|c|}{ Total panel observations 691} & \multicolumn{4}{|c|}{ Total panel observations 688} & \multicolumn{4}{|c|}{ Total panel observations 685} & \multicolumn{4}{|c|}{ Total panel observations 693} & \multicolumn{4}{|c|}{ Total panel observations 689} & \multicolumn{4}{|c|}{ Total panel observations 693} \\
\hline dj R-sq & 0.531 & Akaike IC & -2.779 & Adj R-sq & 0.534 & Akaike IC & -2.781 & Adj R-sq & 0.483 & Akaike IC & -2.674 & Adj R-sq & 0.493 & Akaike IC & -2.692 & Adj R-sq & 0.454 & Akaike IC & -2.625 & Adj R-sq & 0.460 & Akaike IC & -2.630 \\
\hline F-stat & 261.7 & Prob F & 0.000 & F-stat & 263.1 & Prob F & 0.000 & F-stat & 213.9 & Prob F & 0.000 & F-stat & 225.3 & Prob F & 0.000 & F-stat & 191.9 & Prob F & 0.000 & F-stat & 197.8 & Prob F & 0.000 \\
\hline
\end{tabular}

\section{C) Dependent Variable: Financial Markets Index}

\begin{tabular}{|c|c|c|c|c|c|c|c|c|c|c|c|c|c|c|c|c|c|c|c|c|c|c|c|}
\hline \multicolumn{4}{|c|}{ Control of Corruption (CC) } & \multicolumn{4}{|c|}{ Government Effectiveness (GE) } & \multicolumn{4}{|c|}{$\begin{array}{l}\text { Political Stability and Absence of } \\
\text { Violence/Terrorism (PV) }\end{array}$} & \multicolumn{4}{|c|}{ Rule of Law (RL) } & \multicolumn{4}{|c|}{ Regulatory Quality (RQ) } & \multicolumn{4}{|c|}{ Voice and Accountability (VA) } \\
\hline Varia & eff & tat & Prob. & Varia & eff & tat & ob. & Variable & Coeff & t-Stat & Prob. & Vari & Coeff & $\mathrm{t}$-Stat & rob. & Vari & ff & Stat & Prob. & Variable & Coeff & tat & Prob. \\
\hline$C$ & 66 & 7. & 0 & & & 358 & ) & $\mathrm{P}$ & & 2.664 & 8 & RL & & 12 & 0 & & & 5 & 0 & $\nabla_{f}$ & & 97 & 50 \\
\hline GDP & 0.044 & .718 & & DP & & 20.913 & ) & DP & 043 & 84 & 0 & LNGDP & 0.044 & 0 & 0 & GDP & 0.036 & 32 & 0 & DP & 0.041 & 60 & 00 \\
\hline CA & 0 . & 39 & 0. & PCA & 0. & -6.230 & 0 & PCA & 000 & -3.582 & 00 & PCA & 0.000 & 77 & 000 & PCA & 0 & 39 & 0 & |PC & 0 & 57 & 00 \\
\hline & -0.835 & -18.536 & 0.000 & C & -0.652 & -15.068 & 0.000 & & -0.849 & -15.235 & 0.000 & & -0.818 & -19.940 & 0.000 & & -0.644 & -13.873 & 0.000 & & -0.791 & -18.214 & 0.000 \\
\hline \multicolumn{4}{|c|}{ Total panel observations 691} & \multicolumn{4}{|c|}{ Total panel observations 688} & \multicolumn{4}{|c|}{ Total panel observations 685} & \multicolumn{4}{|c|}{ Total panel observations 693} & \multicolumn{4}{|c|}{ Total panel observations 689} & \multicolumn{4}{|c|}{1 panel observations 693} \\
\hline Adj R-sq & 0.421 & Akaike IC & -1.690 & Adj R-sq & 461 & ike IC & -1.759 & Adj R-sq & 0.384 & kaike IC & -1.624 & Adj R-sq & 38 & keIC & -1.814 & Adj R-sq & 0.417 & ke IC & -1.682 & Adj R-sq & 0.425 & Akaike IC & -1.700 \\
\hline stat & 168.2 & $o b F$ & 0.000 & F-stat & 196.6 & $o b$ F & 0.000 & F-stat & 143.0 & $o b F$ & 0.000 & F-stat & 220.6 & 11000 & 0.000 & F-stat & 165.0 & Prob F & 0.000 & F-stat & 171.8 & Prob F & 0.000 \\
\hline
\end{tabular}

Method: Panel Least Squares; Cross-sections included: 44 